Discussion Paper No. 16-041

\title{
Do Municipal Mergers Reduce Costs? Evidence from a German Federal State
}

Sebastian Blesse and Thushyanthan Baskaran

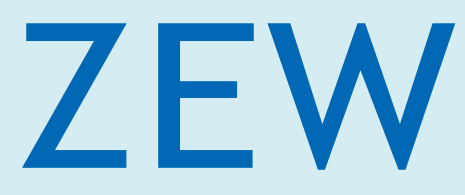

Zentrum für Europäische Wirtschaftsforschung $\mathrm{GmbH}$ Centre for European Economic Research 
Discussion Paper No. 16-041

\section{Do Municipal Mergers Reduce Costs? Evidence from a German Federal State}

Sebastian Blesse and Thushyanthan Baskaran

Download this ZEW Discussion Paper from our ftp server:

http://ftp.zew.de/pub/zew-docs/dp/dp16041.pdf

Die Discussion Papers dienen einer möglichst schnellen Verbreitung von neueren Forschungsarbeiten des ZEW. Die Beiträge liegen in alleiniger Verantwortung der Autoren und stellen nicht notwendigerweise die Meinung des ZEW dar.

Discussion Papers are intended to make results of ZEW research promptly available to other economists in order to encourage discussion and suggestions for revisions. The authors are solely responsible for the contents which do not necessarily represent the opinion of the ZEW. 


\title{
Do municipal mergers reduce costs? \\ Evidence from a German federal state
}

\author{
Sebastian Blesse*† Thushyanthan Baskaran ${ }^{\dagger \dagger}$ \\ ${ }^{\dagger}$ ZEW Mannheim, blesse@zew.de \\ ${ }^{\dagger \dagger}$ University of Siegen, baskaran@vwl.uni-siegen.de
}

First version: December 2013

This version: April 2016

\begin{abstract}
We study the fiscal consequences of municipal mergers by making use of a largescale merger reform in the German federal state of Brandenburg. This reform, which was implemented from 2001 to 2003, led to a substantial reduction in the number of municipalities. Individual mergers were heterogeneous across a number of dimensions, which allows us to contribute to the literature by exploring the consequences of different types of mergers within the same institutional setting. Focusing in particular on the distinction between compulsory and (semi-) voluntary mergers, we implement a difference-in-difference design with panel data from 1995-2010 at the level of post-merger municipalities. We find significant reductions in (administrative) expenditures after compulsory mergers. Voluntary mergers, on the other hand, have no effect on expenditures. We also show that the effects of voluntary and compulsory mergers vary according to further (secondary) characteristics of a merger.
\end{abstract}

Keywords: Municipal mergers, economies of scale, voluntary and compulsory mergers

JEL codes: H11, H72, H77, R53

${ }^{*}$ Corresponding author: Centre for European Economic Research (ZEW), P.O. Box 103443, D-68304 Mannheim, Germany. Tel.: +49 0621 1235-394; Email: blesse@zew.de. 


\section{Introduction}

Many industrialized countries have embarked on large-scale municipal merger reforms in the last few decades (Fox and Gurley, 2006). Policy makers typically initiated these reforms in the belief that larger municipal units can exploit economies of scale in public service provision and thereby reduce costs.11 Whether mergers really entail economies of scale and lower expenditures, however, has not yet been conclusively answered. Some studies suggest insignificant effects or even diseconomies of scale after mergers (Moisio and Uusitalo, 2013; Lüchinger and Stutzer, 2002; Allers and Geertsema, 2014; Fritz, 2013), while others show substantial expenditure reductions Blom-Hansen et al., 2014; Reingewertz, 2012).

The ambiguity in literature is difficult to resolve because existing studies typically vary simultaneously along two dimensions. First, they vary in the country, or more precisely in the institutional setting, that is being studied. Second, studies vary according to the type of the merger process, especially according to whether municipalities had some say in whether and with whom to merge (voluntary mergers) or whether mergers were designed and enforced by the central government (compulsory mergers). As each study typically deals with only either compulsory or voluntary mergers, it is difficult to disentangle the effects of the specific features of a merger reform from the institutional idiosyncrasies of the setting.

In this paper, we revisit the question of how mergers affect municipal expenditures relying on a sample of municipalities in the German State of Brandenburg over the period 1995-2010. Brandenburg merged 1319 municipalities into 266 larger units during the 20012003 period in the context of a major merger reform, while leaving 155 municipalities unaffected. This opens up a natural experiment with which we can identify the causal effect of mergers on a number of municipal expenditure items using difference-in-difference (DD) regressions.

\footnotetext{
${ }^{1}$ Other advantages to larger municipalities might be, for example, the provision of a wider range of public services and goods, the internalization of externalities (Oates, 1972) as well as a greater influence over policies implemented by higher tiers of government (Fox and Gurley, 2006).
} 
One notable advantage of our setting over the existing quasi-experimental literature is that the merger reform in Brandenburg encompassed various types of mergers, and included in particular both voluntary and compulsory mergers. More specifically, the state government of Brandenburg decided in late 2000 to reduce the number of municipalities. Following this decision, municipalities were allowed to choose when and with whom to merge until late 2003. In this sense, mergers were voluntary during this initial period. In late 2003, however, the state government passed a law that enforced mergers of those municipalities that were supposed to merge but had not yet done so, bringing the merger reform to a close $2^{2}$ Besides the voluntary vs. compulsory distinction, the mergers during the reform were also heterogeneous along various other dimensions: e. g. in the size of the affected population, in the number of participating municipalities, and in whether mergers were annexations or fusions. That mergers with different characteristics take place within a single reform helps us to understand in detail how the design of a merger determines its fiscal consequences. As indicated, the previous literature either relies exclusively on big bang type of reforms where municipalities were merged according to the central government's design at the same date or on entirely voluntary mergers that take place in a piecemeal fashion.$^{3}$

Overall, our results indicate that mergers result in economies of scale for administrative expenditures: we observe a negative and statistically significant effect on this expenditure category. On the other hand, we do not identify any significant average effects on total, staff, and current expenditures. However, further analysis reveals significant heterogeneity across different types of mergers. First, we find that the administrative cost savings are mostly due to compulsory mergers. Second, we also observe large negative, albeit insignificant, effects of compulsory mergers on total and current expenditures; for voluntary mergers, on the other hand, our estimates are statistically insignificant and

\footnotetext{
${ }^{2}$ We discuss the selection criteria for (compulsory) mergers further below.

${ }^{3}$ Compulsory mergers are analyzed in Reingewertz (2012) for Israel and Blom-Hansen et al. (2014) for Denmark. In contrast, Lüchinger and Stutzer (2002)), Moisio and Uusitalo (2013) and Allers and Geertsema (2014) study exclusively voluntary mergers in Switzerland, Finland and the Netherlands, respectively.
} 
small in magnitude 4 Third, we find that the effect of voluntary and compulsory mergers varies depending on additional characteristics of a merger: voluntary and, to some extent, compulsory mergers are more effective in reducing costs when more inhabitants are affected; both voluntary and compulsory mergers reduce expenditures more when a larger number of municipalities are involved; annexations tend to reduce costs more than fusions and mixed mergers (which consist of both annexations and fusions).

There are some concerns regarding the validity of the DD design given the characteristics of our setting. Most importantly, the state government did not randomly choose municipalities for mergers. Municipalities may have been chosen for mergers based on expected future fiscal developments. While such expected developments were officially not part of the selection criteria for mergers set out by the state government (the criteria did not refer to any fiscal variables), it is nevertheless possible that the state government implicitly took municipal fiscal trajectories into account. A related concern is self-selection into voluntary mergers. It is possible that those municipalities which decided to merge voluntarily during the reform period expected worse fiscal developments. To address these concerns regarding selection, we show that pre-treatment trends in treatment and control municipalities were reasonably similar and that the main results remain robust if we control for observable time-varying characteristics of municipalities $5^{5}$ Another important concern is possible common pool incentives that may have led to expansions in expenditures in the immediate pre-merger period. We address this issue in robustness tests and show that the results remain robust 6

\footnotetext{
${ }^{4}$ Note that an alternative interpretation of the reduced form effects is that there were cuts in municipal services after compulsory mergers, which then led to declining expenditures. While it would be preferable to explore the evolution of municipal services explicitly by relating proxies for service quantity and quality to mergers, it is difficult to measure quantity or quality of local services. Service quantity is hard to measure comprehensively as municipal tasks are manifold and often carried out by various administrative units. For the same reason, it is difficult to evaluate changes in service quality accurately. Overall, however, it is unlikely that the mergers led to significant cuts in services as the state government did not redistribute (new) tasks or gave guidelines to decrease service provision. Similarly, it is implausible that municipalities would deliberately use the opportunity offered by mergers to cut services to their citizens.

${ }^{5}$ We also explore the robustness of the results regarding selection in further robustness tests reported in the appendix; see Table A.7.

${ }^{6}$ Yet another concern is that an increasing number of municipalities drops successively from the sample, resulting in an unbalanced panel. The reason is that municipalities in Brandenburg started to switch from the cameralistic accounting system to a new accounting system (Doppik - double bookkeeping) in
} 
We are one of the first studies to provide evidence on how voluntary versus compulsory municipal mergers affect economies of scale and corresponding fiscal outcomes within the same institutional framework. 7 Moreover, this paper adds to a relatively small quasiexperimental empirical literature on how fiscal variables evolve after mergers. ${ }^{8}$ Allers and Geertsema (2014), Moisio and Uusitalo (2013), and Lüchinger and Stutzer (2002) analyze voluntary municipal mergers in the Netherlands, Finland, and Switzerland, respectively. These studies find little evidence that economies of scale increase due to mergers. The results for compulsory mergers, as for example in Denmark or Israel, seem to be different. Specifically, Blom-Hansen et al. (2014) and Hansen et al. (2014) find for a Danish merger reform in 2007 that fiscal outcomes improve. Reingewertz (2012) finds that the Israeli merger reform of 2003 reduced total expenditures by about $8 \%$ in the amalgamated municipalities compared to non-amalgamated municipalities. As indicated above, our results confirm that it is the compulsory nature of the merger process itself rather than other institutional peculiarities that results in cost savings following mergers. By the same token, voluntary mergers tend to be less effective in reducing public expenditures.

Fritz (2013) is the only previous quasi-experimental study that explores the fiscal effects of mergers with German data.9 $9^{9}$ He focuses on mergers in the West German state of Baden-Württemberg in 1975 and finds that mergers increase municipal debt and total expenditures. He does, however, not explore whether expenditure effects differ between

2007. Not all municipalities switched immediately (the switch was staggered); but by 2010 all municipalities had switched to the new system. As data from the old and the new accounting system are not comparable, we drop a municipality from the sample when it switches to the new system. The timing of the switch to the new accounting system, however, was not systematically related to the merger reform. A robustness test with a balanced sample reported in the appendix confirms the main results (Table A.5.

Hanes and Wikström (2010) exploit a large scale Swedish merger reform in the 1950s to compare the outcomes of voluntary and compulsory mergers for local population and income growth. The authors find that voluntary mergers perform better with respect to both measures compared to compulsory mergers. However, this contradicts the findings of stronger population growth for less voluntary mergers of Kauder (2014) for West German municipal mergers. However, both papers do not focus on expenditure effects of municipal mergers.

${ }^{8} \mathrm{~A}$ related literature studies how fiscal variables evolve before mergers, for example Jordahl and Liang (2010), Hinnerich (2009), Nakazawa (2013), Saarimaa and Tukiainen (2015), Hansen (2014) and Blom-Hansen (2010).

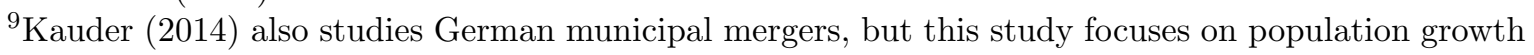
effects of incorporating municipalities into larger cities. He finds that incorporated municipalities grow faster than non-incorporated municipalities. 
voluntary and forced mergers ${ }^{10}$ Another related paper, studying the merger reform Brandenburg is Bruns et al. (2015). The authors find that voluntary mergers took place according to political considerations but do not address fiscal effects of municipal mergers.

The remainder of this paper is structured as follows. The next section discusses the theoretical link between municipal mergers and scale economies. Section 3 provides some institutional details about local public finance in Germany and the merger reform in Brandenburg. We discuss the data in Section 4. In Section 5, we discuss the empirical approach. Section 6 collects the results. Finally, Section 7 concludes.

\section{Municipal mergers, scale economies, and common pool problems}

\subsection{Economies of scale and municipal mergers}

The main motive for municipal mergers is that increasing the size of municipalities might entail cost reductions via economies of scale. Larger municipalities might be able to produce a given output with lower average unit costs. Alternatively, lower service levels might result in lower expenditures even if no scale economies are achieved. However, higher cost efficiency should entail lower spending for given services and vice versa.

Scale economies can emerge after mergers for several reasons. Average costs of production may decline for a given level of municipal services due to more specialization in larger municipalities. That is, it is plausible that small municipalities are not able to efficiently provide certain public goods because of a lack of professionalization. In addition, larger municipalities have more bargaining power vis-à-vis externals (for e.g. private suppliers of inputs) and can reduce purchasing prices. Duplication of certain services can also be avoided, which reduces fixed expenditures at given service levels. However, municipal

\footnotetext{
${ }^{10}$ Note that there is also a descriptive literature on fiscal outcomes of mergers such as Blume and Blume (2007) for Germany, Gordon and Knight (2008) for school districts in the US as well as Nelson (1992) and Hanes (2015) for municipalities in Sweden.
} 
mergers may not lead to observable cost reductions even in the presence of economies of scale if, for example, rigid labor contracts prevent cost reductions by layoffs or wage reductions.

Even though mergers are often initiated to harvest economies of scale, they may in fact entail diseconomies. Costs per residents may be U-shaped; if mergers result in municipalities that are sub-optimally large, costs might increase due to congestion (Reiter and Weichenrieder, 1997). ${ }^{11}$ In addition, voters may voice demands for new public goods once a municipality surpasses a certain size, which would call for a bigger, more diversified, and specialized administration (Brecht, 1932). Municipal size may also increase informational asymmetries between public officials on the local level which might lead to a socially non-optimal service provision. First, bureaucrats may find it easier to expand their budgets above an efficient level and increase slack as politicians and voters are less able to control the activities of the administration (Niskanen, 1968). Second, politicians, too, may free-ride on their informational advantage over their voters and try to capture rents (Oates, 2005).

\section{$2.2 \quad$ Fiscal effects across types of mergers}

While the previous discussion applies to mergers in general, actual mergers vary across a number of dimensions, and these specific characteristics may have distinctive effects on fiscal outcomes.

Voluntary versus compulsory mergers Voluntary agreements should, in theory, be more efficient than compulsory ones as both partners must consider the merger as beneficial. However, it is possible that political transaction costs might be sufficiently large to prevent many economically efficient mergers if they are to be decided voluntarily (Sørensen, 2006). Theoretical work following Alesina and Spolaore (1997) establishes a

\footnotetext{
${ }^{11}$ Whether the costs of service provision are U-shaped is unclear, see Fox and Gurley (2006) for a review.
} 
trade-off between economies of scale and preference heterogeneity when deciding on the size of a political jurisdiction. 12 Consequently, if municipalities can voluntarily decide on mergers, they may choose a less than optimal jurisdiction size (Weese, 2015).

Moreover, voluntary mergers may reduce expenditures less than compulsory ones if local politicians are not entirely benevolent and have a preference for large public sectors for self-serving reasons (Edwards and Keen, 1996). Politicians might then strategically choose amalgamation partners in order to minimize electoral competition in the local council of the future amalgam (Gul and Pesendorfer, 2010; Hyytinen et al., 2014). That is, if municipalities are allowed to choose with whom to merge, they may deliberately merge with those partners that would allow them to extract higher rents by e. g. maintaining current spending levels. With compulsory mergers, as they are designed and enforced by the higher-level governments, such strategic partnerships are less likely.

Finally, voluntary mergers may also be less effective because those municipalities that voluntarily agree to merge may have already cooperated and pooled resources in the premerger period. Consequently, the potential for cost savings by voluntary mergers may be lower (Saarimaa and Tukiainen, 2014).

Other sources of heterogeneity across mergers Other characteristics of mergers may also affect fiscal outcomes, e. g. the size of the affected population. On the one hand, a larger affected population implies a bigger potential for cost savings if population size is sub-optimally low. On the other hand, transition costs might be higher if more inhabitants are involved or if congestion costs are larger than any cost savings. Similarly, the number of affected municipalities may be important for the fiscal consequences of a merger. Finally, note that mergers vary by whether they are annexations or fusions. Formally, annexations are mergers where the municipal code of one municipality is completely adopted by the other municipalities involved in the merger. Fusions are mergers where a new code is being adopted by the post-merger municipality. In practice, there

\footnotetext{
${ }^{12} \mathrm{~A}$ vast empirical literature on the determinants of (voluntary) mergers finds that they are more likely if expected fiscal gains are high and heterogeneity between potential merger partners is low, notably in fiscal (Gordon and Knight, 2009) or political terms (Bruns et al., 2015).
} 
is a dominant partner in annexations while fusions are mergers between equals. Overall, annexations could be either more or less effective than fusions (or "mixed" mergers that comprise both annexations and fusions). On the one hand, an annexing municipality will tend to be substantially larger and thus already have a sophisticated administration, allowing the smaller partners to reduce their administrations. On the other hand, annexations may, for political reasons, involve some concessions of the annexing municipality to the smaller partners. In particular, they may be permitted to temporarily retain some of administrative offices or to increase service provision to the (higher) level of the annexing partner.

\subsection{Common pool problems in pre-merger budgets}

Typically, policy makers are interested in economies of scale that unfold in the aftermath of mergers. However, opportunistic pre-merger behavior may lower the intended postmerger economic benefits and therefore needs to be considered, even if we are primarily interested in the post-reform effects of mergers in this paper. In anticipation of the merger, opportunistic politicians might attempt to free-ride on the debt or the tax base of the expected post-reform municipality, resulting in a pre-merger common pool problem.

There is some evidence, primarily from Nordic countries, that municipalities engage in such opportunistic pre-merger behavior, especially in the year before the merger. Opportunistic behavior has been previously documented for expenditures (Hansen, 2014), debt, and assets (Jordahl and Liang, 2010; Hinnerich, 2009; Saarimaa and Tukiainen, 2015), or budget overruns (Blom-Hansen, 2010). There is also evidence for common pool problems prior to municipal mergers for Japanese municipalities (Nakazawa, 2013). 


\section{Institutional background}

\subsection{Local governance structure in Germany}

The units of analysis in this paper are municipalities in the East German federal state of Brandenburg ${ }^{13}$ Article 28 II of the German constitution (Grundgesetz) guarantees all municipalities the right to run their own affairs. No further details are codified, and hence municipalities duties are specified by state-level legislation.

In practice, municipalities in all states are responsible for the provision of a broad range of public goods and services. In administrative terms, municipal tasks can be divided into three categories: voluntary tasks (freiwillige Selbstverwaltungsaufgaben), own compulsory tasks (pflichtige Selbstverwaltungsaufgaben), and transferred compulsory tasks (übertragene Selbstverwaltungsaufgaben). The degree of discretion municipalities have over these type of tasks decreases successively. Transferred compulsory tasks are, in fact, responsibilities of the state tier, but have been transferred by the state governments to the municipal tier for implementation. Consequently, municipalities have no discretion on whether and how to fulfill these tasks. Examples for transferred compulsory tasks is the guaranteeing of public order (Ordnungsverwaltung). Own compulsory tasks are tasks that municipalities must fulfill, but they have discretion about how to fulfill them. For example, child care is an own compulsory task. Municipalities have to guarantee some minimum amount and quality of child care, but can expand child care facilities above these minimum requirements at their discretion. Finally, voluntary tasks are entirely under the discretion of municipalities. They can decide to not engage in in these tasks at all or to invest significant resources. An example for voluntary tasks is the provision of cultural venues, e. g. theaters and museums. Various social serves are also important voluntary tasks, for example care for the old or the poor ${ }^{14}$

\footnotetext{
${ }^{13}$ Germany has a complex federal structure of governance, but consists mainly of three governmental tiers. In addition to the national government, there were 16 federal states and 11,292 municipalities in 2011 (Statistisches Bundesamt, 2013).

${ }^{14}$ The share of local government expenditures in GDP in Germany according to the OECD was about $7 \%$ in 2014, which is lower than in e. g. Nordic countries (which ostensibly have the largest local
} 
Besides these significant responsibilities at the expenditure side of the budget, German municipalities also have considerable revenue autonomy, including revenue sources like user charges, several taxes like the trade tax (Gewerbesteuer) or property taxes (Grundsteuer) as well as remunerations for benefits and services (Zimmermann, 1999). In summary, municipalities in Germany are important and multipurpose economic actors 15

\subsection{Municipal merger reform in Brandenburg}

\subsubsection{Reasons, aims and process of the reform}

In order to achieve a more efficient local government structure, many West-German states implemented large-scale merger reforms in the 1960s and 1970s. No comparable reforms were enacted in the German Democratic Republic (GDR) as the country was highly unitary. Therefore, subnational governments, and in particular the municipalities, were presumably considered to be too unimportant to warrant the effort of large-scale merger reforms. After German reunification, however, the administrative structure of WestGermany was adopted by the newly formed Eastern States and municipalities became important pillars of public administration. Given the absence of merger reforms, however, Eastern municipalities tended to be very small. Therefore, attempts were made to reduce the number and increase the size of municipalities in the Eastern States Landtag Brandenburg, 2012).

In Brandenburg, the Ministry of Interior is in charge of local governments. The ministry's policy was always supportive to mergers, both on the municipality and district level. Despite the installation of municipal associations in 1992 and the reduction of rural districts in 1993 from 38 to 14, state officials continued to diagnose a chronic lack of administrative capacity and efficiency (Landtag Brandenburg, 2012). In particular, 58.2\% of the municipalities in Brandenburg had less than 500 residents, and especially these very government sector in the OECD), but comparable to many other OECD countries (e. g. Austria, Belgium, Canada). Also, the share local expenditure in total government expenditure was about $17 \%$ in 2014 .

${ }^{15}$ For a more comprehensive review of the German federal system, see Zimmermann (1999). 
small rural municipalities have been perceived to fulfill their public service obligations neither sufficiently nor efficiently (Ministerium des Innern Brandenburg, 2011).

For such small municipalities, municipal mergers were seen as an instrument to achieve cost savings ${ }^{16}$ Mergers were expected, in particular, to achieve higher efficiency in terms of fiscal and administrative capacities (Landtag Brandenburg, 2000) ${ }^{17}$ Immediately after the state elections at the end of 1999, the new state government therefore agreed on a comprehensive merger reform. Subsequently, the state parliament instructed the government to suggest a concept for a reform by mid-2000. The state government then proposed a concept called "guidelines for the development of rural structures" (Leitlinien der Landesregierung für die Entwicklung der Gemeindestruktur im Land Brandenburg) in July 2000, which was passed in September 2000 by the state parliament.18

The guidelines stipulated that after the reform, municipalities should have no less than 5000 inhabitants. In cases where it was not possible to create new independent municipalities, existing municipalities were expected to organize within a municipal association. In these cases, individual municipalities belonging to an association should not have less than 500 inhabitants. Associations themselves should have no less than 5000 inhabitants and encompass 3 to 6 municipalities. The travel distance to the seat of the administration of the association should also not be larger than $20 \mathrm{~km}$. The guidelines also spelled out further criteria, for example that district and existing municipal association boundaries should be respected in a municipal merger, i. e. mergers across districts or associations were discouraged, but exceptions were possible under certain conditions (Landtag Brandenburg, 2000).

\footnotetext{
${ }^{16} \mathrm{An}$ unsuccessful initiative in support of voluntary mergers was launched in the beginning of 1998 (Landtag Brandenburg, 1998). The few resulting voluntary mergers by this act and their effects are addressed in the robustness checks of Section 6. Particularly, we obtain similar results regardless of whether the prior mergers are considered in the analysis or not.

${ }^{17}$ Another aim of the reform was to ensure that enough candidates would be available to contest elections for local government positions (Ministerium des Innern Brandenburg, 2001). Also, larger local units were seen as an instrument of improved regional planning and a more professional public service provision.

${ }^{18}$ The timeline of the reform is sketched in Figure A.1 in the appendix.
} 
Following the publishing of the guidelines, a voluntary merger phase was initiated from the beginning of 2001 19 until March 2002. Municipalities that merged voluntarily could chose with whom and when to merge within the criteria of the reform guidelines. Voluntary mergers took place in the form of a contract between the merging municipalities, which had to be accepted by the local councils of all involved municipalities (and for municipality with fewer than 5000 inhabitants additionally by a referendum). All assets, debts and administrative staff of amalgamating pre-reform municipalities were to be taken over by the respective post-reform municipality.

Voluntary mergers, even if accepted by the council (and possibly by a referendum), were subject to the final approval of the state interior ministry. Approval was generally conditioned on whether the newly created municipalities fulfilled the criteria spelled out in the guidelines: 20 To support voluntary mergers, a "municipal reform law" (Gemeindereformgesetz) was passed in March 2001 (Ministerium des Innern Brandenburg, 2001). The latter provided a financial incentive scheme for municipal mergers within the voluntary time period with a maximum premium of 2.5 million Euros per newly created municipality from the state government. In general, however, these amalgamation grants only made up a relatively small fraction of total expenditures ${ }^{21}$

On March 2003, the state government passed six "laws of reorganization" (Neugliederungsgesetze) to finally complete all those mergers that did not fulfill the selection criteria of the guidelines (Landtag Brandenburg, 2003). The compulsory mergers hence took place on the basis of laws rather than contracts. While the laws on compulsory mergers were drafted, municipalities could still agree on voluntary mergers. If the mergers were admissible under the guidelines, they were approved and the draft of the law was changed accordingly. The remaining mergers became effective by 26th October 2003 and the municipal merger reform was finally put to an end.

\footnotetext{
${ }^{19}$ In December 2000 there was already a merger involving the new municipality Teichland.

${ }^{20}$ However, according to the state government, voluntary mergers could be denied if, for example, a particular merger would make it impossible for other municipalities to fulfill the guidelines after their mergers, or if there were "obviously" better partners for mergers available.

${ }^{21}$ Specifically, amalgamation grants only made up about 6 to 7 percent of total expenditures even among those municipalities that received such grants.
} 
In general, municipalities that merged during the merger reform did not satisfy the criteria in the guidelines while those that remained intact did. Nevertheless, the reform and its implementation were extremely controversial. Legal challenges against the compulsory mergers were mounted at the end of reform, resulting in 255 cases at the state's constitutional court. The main argument of the complaints were based on the municipal right for local autonomy. However, except for two formal mistakes, no revisions to the reform were made until the end of the lawsuits in 2006 (Verfassungsgericht Brandenburg 2006).

The merger reform reduced the number of municipalities substantially, from 1474 (end of year 2000) down to 421 in 2004.22 Mergers occurred also before the reform ${ }^{23}$ but the reform increased the numbers of completed mergers drastically (Figure 1). The number of municipalities remained largely stable after the end of the reform ${ }^{24}$ During the reform, 1319 municipalities merged to 266 larger units, with the merged units encompassing from 2 up to 22 pre-reform municipalities. 103 of these mergers were compulsory while 163 were voluntary. 155 municipalities were left unaffected. The share of small jurisdictions with less than 500 inhabitants declined from $58.2 \%$ in 1999 to $1.4 \%$ of all municipalities in 2004. Figure A.2 in the appendix reports maps of pre- and post-reform municipal boundaries (i. e. in 1999 and 2005).

\footnotetext{
${ }^{22}$ In fact, there were 438 municipalities at the end of 2003 which is formally the terminal year of the reform. However, some further boundary changes took place in 2004, which results our sample of 421 post-merger municipalities. In the regressions, we drop twelve more municipalities from the sample for various reasons (see below).

${ }^{23}$ Note that we classify municipalities that merged before the merger reform but did not experience a merger during the reform as control units in the empirical analysis below. This may cause us to under-estimate the treatment effect of mergers. However, we show in a robustness test (Table A.6) that dropping municipalities that had mergers between 1990 and 2000 from the sample does not affect the main results.

${ }^{24}$ Only two further mergers took place after the end of the reform, i.e. in 2009 and 2014 (Amt für Statistik Berlin-Brandenburg, 2013).
} 


\section{Data}

\subsection{Variables}

Table A.1 in the appendix describes all outcome and explanatory variables used in the subsequent analysis. For expenditures as well as for several control variables, we use administrative data from the state statistical office (Statistisches Landesamt Berlin-Brandenburg, SBB). All budget figures are based on yearly realized municipal accounts. Monetary units are deflated by the consumer price index and are expressed in constant Euros with the base year 2010 .

\subsection{Units of observation}

We use a panel of municipalities of the federal state Brandenburg for the years 1995-2010. All variables for these municipalities have been aggregate to post-reform boundaries by the state statistical office ${ }^{25}$ Therefore, budgetary outcomes for merged units before the treatment are the sum of all respective pre-reform municipalities. The final analysis covers 257 post-reform municipalities that were part of municipal mergers (treatment group) and 152 municipalities that were unaffected from boundary changes (control group). This sample (409 municipalities) is smaller than the full sample of 421 post-reform municipalities (266 merged and 155 non-merged) since we drop twelve municipalities for various reasons 26

\footnotetext{
${ }^{25}$ Thus, we follow much the previous literature which uses data aggregated to post-reform boundaries, for e.g. Reingewertz $(2012)$.

${ }^{26}$ First, the district-free (kreisfrei) cities Frankfurt/Oder, Potsdam, Brandenburg an der Havel and Cottbus have a different administrative status than other municipalities. As their status as district-free suggests, they carry out both municipal and district-related tasks. Thus, one cannot compare districtfree with district-affiliated municipalities and we exclude the four district free cities from the sample. We also drop six municipalities which experience boundary changes after the official reform end in October 2003: Königs-Wusterhausen, Heiligengrabe, Neuhausen/Spree, Spremberg, Bad Freienwalde and Welzow (LDS, 2005). Finally, the municipalities of Hohensaaten and Haidemühl are excluded as no budgetary data at the level of the 2012 boundaries is available.
} 


\subsection{Descriptive statistics on municipal mergers}

We distinguish in the subsequent analysis between three types of post-merger municipalities: those that were not merged, those that were merged compulsorily, and municipalities that merged voluntarily. While it is straightforward to distinguish between merged and non-merged municipalities, it is less clear how to distinguish between compulsorily and voluntarily merged municipalities. As the post-merger municipalities were typically created by amalgamating more than two municipalities, some experienced both voluntary and compulsory mergers. We define a post-merger municipality as part of a compulsory merger if at least one merger happened compulsorily, even if this municipality also experienced a number of voluntarily mergers ${ }^{27}$

Table 1 collects summary statistics on the outcome and control variables. As could already be inferred from our description of the merger process above, these statistics confirm that the majority of post-merger municipalities in our sample were created through amalgamations - about 63 percent. Also, about $40 \%$ of post-merger municipalities were created through entirely voluntary mergers while about $23 \%$ municipalities had at least one compulsory merger.

Table 2 compares characteristics of non-merged against merged municipalities (Panel A) and of voluntarily against compulsorily merged municipalities (Panel B) in 2000, the year before the start of the merger reform. Clearly, these groups are different across a range of characteristics even as the data is consolidated to post-merger units. For example, the municipalities that were eventually merged have, when aggregated to the post-merger boundaries, higher total, administrative, and current expenditures than nonmerged municipalities. On the other hand, there are no differences in population size, which, however, is to some extent expected given that it was an explicit goal of the merger reform to increase the size of the merged municipalities.

\footnotetext{
${ }^{27}$ We explore in Table A.8 in the appendix whether the share of actually compulsorily mergers within a merger defined as compulsory matters for fiscal outcomes. The results are similar to our baseline findings. Another strategy to explore the robustness of the results to this issue is to drop municipalities that underwent multiple mergers. We implement this strategy in Table A.9 in the appendix and find that the results remain largely robust.
} 
We also observe significant differences in characteristics between municipalities that underwent compulsory and voluntary mergers. For example, municipalities that underwent compulsory mergers had generally higher expenditures. As discussed above, this may suggest that municipalities that merged voluntarily already cooperated in the pre-merger period, allowing them to have somewhat lower expenditures already in the pre-merger period. Similarly, post-merger population size of municipalities with compulsory mergers is significantly higher than that of voluntary mergers, which may indicate that these municipalities strategically choose partners that would help them to surpass some minimum threshold in order to avoid a compulsory merger.

\section{Empirical framework}

As the three groups of (voluntarily, compulsorily and non-merged) municipalities have significantly different pre-merger characteristics, we implement a difference-in-differences (DD) design in a regression framework to consistently estimate the expenditure effects of mergers. The DD design accounts for all time-invariant characteristics of municipalities that could be correlated with whether a municipality underwent a (voluntary or compulsory) merger. More specifically, we estimate the following model:

$$
y_{i t}=\alpha_{i}+\gamma_{t}+\beta \text { Amalgamation }_{i t}+\theta X_{i t}+\epsilon_{i t}
$$

where $y_{i t}$ is one of four expenditure items for municipality $i$ and year $t$ (total expenditures, staff expenditures, administrative expenditures, and current expenditures) in Euros per capita.

The treatment indicator is defined as Amalgamation $=($ Amalg $*$ Post $)$, i. e. it is an interaction variable between a dummy indicating amalgamated municipalities, Amalg, and a dummy indicating the post-merger period, Post. The dummy Amalg is set to 1 for all municipalities which experienced a merger during the reform. The dummy Post is set to 1 in the year in which the last merger in the context of the merger reform had 
been completed and to 0 for all the years before ${ }^{28}$ That is, assume municipalities A and B merge in 2001, creating municipality AB. In 2003, AB then merges with C, creating ABC. The Post dummy is 1 only after $2003{ }^{29}$

Moreover, we control for all time-invariant characteristics of a given municipality by including municipality-specific fixed effects $\alpha_{i}$ and common time effects by accounting for year-specific effects $\gamma_{t}$. We also control in some specifications for a vector of covariates $X$. The covariates cover fiscal, demographic, and political characteristics of municipalities. Specifically, to account for demographic factors we include the population, population squared, population density, and the share of old in a municipality; to account for fiscal and economic factors, we include the amount of rule-based grants per capita, the amount income tax revenues per capita 30 , and the amount of amalgamation grants, i. e. grants allocated to municipalities that merged voluntarily. ${ }^{31}$ Finally, to account for political factors, we include the share of left-wing parties in the local council ${ }^{32} \epsilon_{i t}$ denotes the error term. To account for heteroscedasticity and autocorrelation, we always report results based on robust and clustered standard errors. Standard errors are clustered at the municipal level.

As the DD design includes municipality-specific fixed effects and thus accounts for time-invariant municipal characteristics, the main identifying assumption is that treated and control municipalities would have had parallel trends in expenditures in the absence of treatment (Angrist and Pischke, 2009). This assumption can be validated by exploring pre-treatment expenditure trends in the three groups of municipalities (non-merged,

\footnotetext{
${ }^{28}$ Note that, as mentioned in footnote 19 , one municipality, Teichland, already merged at the end of December 2000. As this merger happened in December (and also for simplicity), we set for this municipality the treatment dummy to 1 from 2001 onwards rather than from 2000.

${ }^{29}$ However, we show in a robustness test in Table A.4 that setting the Post dummy to 1 after the first merger does not substantively change the results.

${ }^{30}$ Municipalities are entitled to a fixed fraction of all income tax revenues collected within their administrative boundaries. As the income tax rate is constant throughout the federation (municipalities have no autonomy to change rates or bases), the municipal income tax share is entirely determined by the value of the base, which will evolve according to economic conditions.

${ }^{31}$ Note that amalgamation grants were paid also for the (voluntary) mergers that happened before and after the merger reform. We neglect these pre- and post-reform grants; i. e. we only consider those grants that were paid during the reform in the regressions.

${ }^{32}$ These variables are described in more detail in Table A.1
} 
voluntarily merged, compulsorily merged). If the three groups had experienced similar trends in the pre-merger period, it is plausible that expenditures would have continued to evolve in a parallel fashion in the post-treatment period in the absence of mergers 33

Figure 2 shows the average development of the four expenditures items in the three groups. Note that the two vertical lines indicate the starting date and the terminal date of the merger reform in the years 2001 and 2003, respectively. Trends in the premerger period are largely parallel for staff and administrative expenditures. For total expenditures, trends are also largely similar with the exception that in one year, 1998, expenditures increase in compulsorily merged municipalities while they decline in nonmerged and voluntarily merged municipalities.

Similarly, pre-merger trends for current expenditures are roughly identical with the exception that expenditures decline in 1997 in non-merged and voluntarily merged municipalities while they increase in compulsorily merged municipalities. While these onetime divergences arguably do not invalidate the common trends assumptions, we include further below the set of time-variant covariates mentioned above to account for such divergences across the three groups. Figure A.3 in the appendix indicates that these time-varying covariates account reasonably well for such one-time divergences. That is, when we plot the residuals from a regression of the four expenditure categories on the covariates over time, we find for all of them essentially parallel trends across the entire pre-treatment period.

\footnotetext{
${ }^{33}$ We also report in the appendix further robustness test that explore the issue of selection. Specifically, Table A.7 reports regressions with only municipalities that underwent mergers included in the sample. Identification in these regressions relies on the timing of mergers and is reasonably robust to violations of the parallel trends assumption. The results confirm the baseline findings.
} 


\section{Results}

\subsection{Graphical evidence}

To gain a first impression of the effect of mergers, we illustrate graphically how the outcome variables have evolved over the period 1995-2010. Again, we rely on Figure 2, which, as discussed, traces mean total, staff, administrative, and current expenditures per capita in treatment and control municipalities over time.

First, the plots show that mean total expenditures for compulsorily merged municipalities have been consistently higher than for their non-merged counterparts. Municipalities that underwent voluntary mergers also had on average higher expenditures than nonmerged municipalities, except in one year. Overall, this suggests that smaller administrative units had higher costs, presumably because they were unable to fully exploit scale economies. This gap between municipalities that merged compulsorily and non-merged municipalities has lowered immediately after the reform. In particular, expenditures of compulsorily merged municipalities drop more sharply than those of non-merged municipalities from 2001 to 2003. The decline in the gap remains for the first few post-merger years.

In the very long-run, we observe that the gap between compulsorily merged and nonmerged municipalities starts to increase again. This, however, is plausible because municipalities successively drop from our sample due to the switch to the new accounting system. Thus, the averages in the later periods are calculated for somewhat different groups of municipalities than in the earlier post-merger period and thus not entirely comparable. Overall, the graphical evidence suggests that the compulsory mergers led to cost savings. For municipalities that merged voluntarily, the gap to non-merged municipalities does not narrow substantively between 2001 and 2003; and there is also no evidence for cost savings in the long-run.

Note also that some increase in expenditures in voluntarily and compulsorily merged municipalities is observable in the early part of the merger reform (even as there is also 
an increase in non-merged municipalities). This may be, as discussed in Section 2.3, due to attempts by municipalities selected for mergers to exploit the post-merger common pool by expanding expenditures in the pre-merger period. Yet, this observation does not invalidate our DD design, as any divergences in trends in the post-2000 period can be related to the merger reform. However, it suggests that such pre-merger effects should be accounted for in the empirical design. We explore this issue in a robustness test.

\subsection{Expenditure effects of generic mergers}

We report, as a benchmark, in this section the regression results for the four expenditure categories while not differentiating according to the type of merger. Specifically, Table 3 collects the results of estimating Equation 1. We estimate regressions with and without the time-varying covariates mentioned above. Some of these control variables are arguably not exogenous, but it would nonetheless be reassuring if the results for the treatment variable remains unaffected.

The estimates imply that merged municipalities witness a significant decline in administrative expenditures in the post-merger period, about 10 to 12 Euros per capita. Other expenditure items are seemingly not affected by mergers. Overall, these results suggest that generic mergers entail significant economies of scale for administrative expenditures but not for other expenditure items. To evaluate the size of the effect, compare the estimates to average administrative expenditures per capita during the sample period as reported in Table 1. Accordingly, a merger would reduce administrative expenditures by about 8 to $10 \%$ of mean administrative expenditures or by about $1 \%$ of mean total expenditures. However, as indicated above the average treatment effects may mask significant heterogeneity according to the type of merger. In the following, we thus explore heterogeneity across various dimensions. 


\subsection{Voluntary vs. compulsory mergers}

Much of the previous literature indicates that whether a merger is voluntary or compulsory matters for how it will affect fiscal outcomes. However, the available evidence on compulsory and voluntary mergers is from different countries, and it is unclear whether any differences in fiscal outcomes are due to country-specific institutional features or due to inherent differences between compulsory and voluntary mergers. One advantage of our setting is that we can explore within the same institutional context whether voluntary and compulsory mergers have different treatment effects.

In Table 4 , therefore, we report regression results from a variant of Equation 1 where we estimate separate treatment effects for voluntary and compulsory mergers. Note first that we obtain significant treatment effects on administrative expenditures only for compulsory mergers. Specifically, administrative expenditures decline significantly by around 23 to 25 Euros per capita after a compulsory merger, while there is no decline for voluntary mergers; the coefficient estimate is neither statistically nor in magnitude distinguishable from 0. Accordingly, compulsory mergers may reduce administrative expenditures by about $20 \%$ of mean administrative expenditures or by about $1.7 \%$ of mean total expenditures.

Second, we also observe large negative estimates for compulsory mergers on total and current expenditures. For example, total expenditures decline by 75 Euros per capita according to Model (II) and current expenditures by 37 Euros per capita according to Model (VIII). While these estimates are insignificant, their magnitude indicates that compulsory mergers tend to have a negative effect on total and current expenditures. When compared to average total and compulsory expenditures as reported in Table 1 , the estimate imply that compulsory mergers reduce total expenditures by about $5 \%$ and current expenditures by about 3 to $4 \%$. As total and current expenditures are larger expenditure categories than administrative expenditures, these small relative reductions nonetheless imply larger absolute cost savings than for administrative expenditures. One expenditure item where we do not see even small effects for compulsory merger are staff 
expenditures, which suggests that this expenditure item is highly persistent. This is plausible as public sector labor contracts are difficult if not practically impossible to terminate 34

\subsection{Exploiting the pre-merger common pool}

One concern with the previous results is that municipalities may expand expenditures before the mergers in order to exploit the post-merger common pool. That is, any debt accumulated by the pre-merger municipalities has to be repaid by the post-merger municipality, and thus in part by the other municipalities that were part of a merger (Hinnerich, 2009; Saarimaa and Tukiainen, 2015). Consequently, the decline in expenditures after compulsory mergers may be simply a return to the norm rather than indicative of cost savings. Some indication that there may be pre-merger expansions was already observable in Figure 2, where merged municipalities witnessed a fairly steep initial increase in expenditures in the early part of the merger.

To explore this issue explicitly, we estimate two types of models. First, we replicate the previous regressions but include pre-merger dummies for voluntary and compulsory mergers. The results are collected in Models (I) to (IV) of Table 5; they indicate that there are indeed some pre-merger effects for compulsory mergers. Specifically, total, administrative, and current expenditures are significantly higher one to two years before a compulsory merger than in other years. For voluntary mergers, we do not observe any common pool effects. Overall, these results are plausible as municipalities that were merged forcibly should have had strong incentives to exploit the common pool and they ostensibly did not want to be part of that common pool in the first place. In contrast, municipalities that merged voluntarily chose their partners themselves, and thus excessive

\footnotetext{
${ }^{34}$ We have also explored whether the effect of mergers vary over time. These estimates, collected in Table A.3 in the appendix, are mostly suggestive as the sample becomes increasingly unbalanced as we move further in time. Nevertheless, these results indicate that the decline in administrative expenditures remains constant over time. Similarly, compulsory mergers tend to have a reasonably large, but again insignificant, effect on total and current expenditures for a few years after the completion of the merger. In contrast, we do not observe significant effects on staff expenditures even in the long-run.
} 
exploitation of the common pool may have led to the cancellation of the merger and thus would have been ultimately self-defeating ${ }^{35}$ In any case, note that even if there are common pool problems for compulsory mergers, we obtain negative coefficient estimates for the post-merger dummy after explicitly accounting for the pre-merger effects in the regressions for administrative expenditures. That is, there seem to be genuine cost savings even as there was seemingly a deliberate increase in expenditures before compulsory mergers. We also estimate negative effects for total and current expenditures, but these estimates are smaller than in the baseline regressions once we include covariates.

Columns (V) to (VIII) of Table 5 reports results from an alternative approach to account for pre-merger effects. Here, we simply drop all years after the start of the merger reform and before the completion of the last merger within a municipality from the sample (i. e. the sample only covers the periods 1995-2000 and 2005-2010). As the merger reform was fairly unexpected, any incentives to exploit the common pool should exist only in these few years. We observe that even without any observations from these years, the negative treatment effect of compulsory mergers remains. The main difference is that when we include control variables, the magnitude of the estimated coefficient in the total and current expenditures regressions is somewhat smaller than previously.

\subsection{Further heterogeneity across merger types}

As the previous results indicate, voluntary and compulsory mergers have different expenditure effects. However, mergers vary also along a number of further dimensions. In this section, we explore these additional type of heterogeneity in mergers. The specific questions we ask is whether voluntary and compulsory mergers are more effective (i) if the total affected population is larger; (ii) if more municipalities participate in a merger; and (iii) if a merger is an annexation rather than a fusion.

\footnotetext{
${ }^{35}$ However, Saarimaa and Tukiainen (2015) find that in Finland, pre-merger common pool effects exist even for voluntary mergers.
} 
To explore these questions, we estimate variations of Equation 1 where we interact the dummies for voluntary and compulsory mergers with variables that capture the abovementioned dimensions of heterogeneity in mergers. Specifically, Panel (A) in Table 6 reports results where we interact the merger dummies with the size of the population of a post-merger municipality. We find that, in general, voluntary mergers are more effective in reducing costs when more inhabitants are involved. One exception, however, seems to be staff expenditures, which increase with the size of the affected population. For compulsory expenditures, we find generally no significant interactions; the exception is current expenditures, which decline more in larger mergers. That there are generally larger cost savings if more inhabitants are involved is, as discussed above, plausible as the potential for cost savings is bigger ${ }^{36}$ This may matter especially for municipalities that merged voluntarily, as they already had relatively lower expenditures than compulsorily merged municipalities. The positive interaction between the size of the affected population and voluntary mergers for staff expenditures is surprising, but may be again explained by the duration of public sector employment contracts. Municipalities that have more inhabitants also have more administrative staff, which are harder to cut even in the medium run than other expenses.

Panel (B) reports results for models where we interact the merger dummies with the number of participating municipalities. Here we find significant interactions for almost all expenditure categories and for both voluntary and compulsory mergers. Specifically, expenditures are generally lower for voluntary mergers when more municipalities participate. The exception is again staff expenditures, which increase with the number of municipalities. For compulsory mergers, we find that both total and current expenditures decline more if a larger number of municipalities participate. These results are in line with those for the interactions with population size, and can be rationalized accordingly.

Panel (C) estimate models where we differentiate between annexations and fusions. To explore different fiscal effects of these two types of mergers, we interact the merger

\footnotetext{
${ }^{36}$ This also suggests that the municipalities involved are still below their optimal size for local service provision.
} 
dummies with a dummy for annexations (thus fusions and mixed mergers are the reference category). We find mostly insignificant effects; however, the magnitude of the interaction effects is fairly large. As the estimate is also typically negative, it seems that annexations lead to more cost savings than the other type of mergers. Also, for administrative expenditures, the interaction effect is negative and significant, indicating that the savings in administrative costs after compulsory mergers are mostly due to annexations. One exception are again staff expenditures, which seem to increase more for voluntary mergers that are annexations. As discussed above, one plausible explanation for why annexations are more effective may be that it is relatively easy and straightforward to cut non-staff related administrative expenditures in the municipalities that had been annexed. The positive effect on staff expenditures is again surprising. It may be that in an annexation, staff in the smaller partners has to be retained even if it is superfluous due to the long-lasting employment contracts. In fusions, on the other hand, staff could be shared and/or shifted across the (typically equally sized) merging municipalities to enhance administrative efficiency.

\subsection{Effects on revenues, fiscal pressure, and debt}

If mergers affect expenditures, it seems likely that they should also have consequences on other fiscal variables. Specifically, declining expenditures should be used by municipalities to either reduce deficits and repay debt or to lower the fiscal burden on their citizens by cutting taxes, user fees etc ${ }^{37}$ In this section, therefore, we explore how the cost savings that we identified for compulsory mergers affect the revenue side of the budget. Table 7 reports the results for total revenues, tax revenues, fiscal pressure (which is a proxy for the fiscal stance of a municipality in the cameralistic accounting system) ${ }^{38}$, and for debt.

\footnotetext{
$\sqrt[37]{\text { Reingewertz }(2012)}$ explores effects on tax revenues to infer how administrative quality has evolved. The idea is that tax revenues may decline due to evasion if the quality of the tax administration suffers due to the expenditure cuts. In Germany, however, tax administration (even for local taxes) is under the purview of the state governments.

${ }^{38}$ Primary surplus net of debt repayments and accrued liabilities.
} 
We observe statistically significant effects only for total expenditures. Specifically, compulsory mergers lead to a reduction in total revenues by about 92 Euros per capita when we omit covariates. With covariates, we observe an insignificant but still fairly large reduction in total revenues by about 65 Euros per capita. We do not observe any notable effects on tax revenues, fiscal pressure, and municipal debt. Overall, these results suggest municipalities use the cost savings not to repay debt or to alleviate their fiscal pressure. It seems that municipalities use the cost savings to reduce the fiscal burden on their citizens. However, since we do not observe effects on tax revenues, municipalities arguably cut non-tax revenue sources. For example, they may be levying lower user fees or request fewer returns from municipal utilities, which would allow the latter to charge lower fees to citizens 39

\subsection{Discussion}

To summarize, it seems that compulsory mergers reduce at least administrative and possibly also total and current expenditures in the years following the merger, even as municipalities subject to compulsory mergers seem to increase expenditures immediately before the merger. Voluntary mergers, on the other hand, result in no cost savings, but there is also no pre-merger increase in expenditures.

One reason why treatment effects are essentially zero for voluntary mergers might be, as discussed above, that municipalities which merge voluntarily choose partners such that they only barely fulfill the criteria set out by the state government regarding minimum population of post-merger municipalities. Thus, municipalities that merged voluntarily may still be too small to experience significant scale economies (See Table 2). Municipalities that merge voluntarily may also have already cooperated in the pre-merger period and thus have had lower expenditures.

\footnotetext{
${ }^{39}$ We attempted to explore whether any revenue categories witness a particularly large decline after compulsory mergers, but did not find any strong evidence in this regard; it hence appears that municipalities spread the savings across a broad range of revenue sources.
} 
A further reason, not discussed above, may be that voluntarily merging municipalities in Brandenburg are somewhat weaker fiscally. In 2000, average revenues per capita are about 120 Euros per capita lower while grant receipts are about 20 Euros per capita higher. These differences are statistically significant according to the t-tests reported in Table 2. Municipalities marked for mergers might decide to merge early - and thus voluntarily - because they are fiscally weaker than those who hang on until the end of the reform period, when they were forced to merge. Another reason why observed economies of scale are smaller could therefore be that municipalities that merged voluntarily are a bad selection within the group of all merged municipalities.

However, while differences in population size or fiscal strength may be responsible for why voluntary mergers seem to be ineffective, we can test whether any differences in such municipal characteristics drive the results by explicitly including fiscal characteristics as covariates in the regressions. However, the inclusion of such covariates does not substantively affect the estimates for the merger dummies, diminishing the persuasiveness of this argument.

Another possible reason for these results, also not explicitly discussed above, is that municipalities that merged voluntarily received extra grants. If these grants were used to expand expenditures and if these expenditures had persistent effects, we may obtain estimates for voluntary mergers that are biased upwards. However, we control for these grants in the regressions and find that their inclusion does not substantively change the estimates. Moreover, these grants were only one-time payments, so their effects should fade over time, and they were also not very large when compared to total expenditures.

Hence, the differences in the expenditure effects of compulsory and voluntary mergers do not seem to be, at least not primarily, due to differences in municipal characteristics or additional grant receipts by municipalities that merger voluntarily. Rather, the ability to choose economically suboptimal partners and the possible existence of pre-merger cooperation agreements seem to be more likely explanations for the relative ineffectiveness of voluntary mergers (e.g. Weese (2015); Hyytinen et al. (2014)). 


\section{Conclusion}

This paper explores the impact of municipal mergers in the German federal state of Brandenburg on municipal expenditure levels. Difference-in-difference estimations with a panel of municipalities in Brandenburg for the years of 1995-2010 show that administrative expenditures decline after mergers. We also find reductions in total and current expenditures, but these are typically statistically insignificant. The reductions are mainly due to compulsory mergers; voluntary mergers do not lead to expenditure cuts. Besides the voluntary vs. compulsory distinction, we also observe significant heterogeneity across merger types. Mergers with a larger number of participants and those by annexations seem to be more effective in reducing costs. The size of the affected population also matters to some extent.

With respect to external validity, our results arguably carry over to other East-German states given the similarities between them and Brandenburg. Despite socio-economic differences between East and West Germany, our results should also be relevant for the western states given that local budgeting and merger processes are quite similar 40 International comparisons are more difficult as the organization of the subnational tier varies significantly even among industrialized countries. However, that our results are in line with the findings regarding the expenditure effects of compulsory mergers in Denmark and Israel while our findings regarding voluntary mergers resemble those from Finland and the Netherlands indicates that our results are relevant for industrialized countries as well.

Overall, our findings suggest that policy makers should make further use of the instrument of compulsory mergers to harvest scale effects and reduce especially administrative costs. On the other hand, one should not neglect the non-monetary costs of mergers, such as less local democracy and lower satisfaction of the local electorate (Lassen and Serritzlew, 2011a b; Hansen, 2015). Such political costs might be lower with voluntary

\footnotetext{
${ }^{40}$ Also, similar to the setting in Brandenburg, the West-German municipal mergers in the 1960s-1970s were typically staggered and involved an initial (semi-) voluntary phase and a terminal compulsory phase Kauder, 2014).
} 
mergers as these likely result in less heterogeneous preferences within the merged municipalities and thus possibly lower voter frustration. Whether a specific type of merger is on balance beneficial should, therefore, be decided on a case-by-case basis.

\section{Acknowledgments}

We thank two anonymous referees for their helpful comments and suggestions. We are also grateful to Ronny Freier, Alfons Weichenrieder, Benedikt Fritz and the participants of the RGS Doctoral Conference in Dortmund and an internal seminar at the ZEW Mannheim for comments on an earlier draft. We acknowledge excellent research assistance from Nuri Khayal. We also thank the Ministry of Finance and the Ministry of Interior of Brandenburg for providing data on merger subsidies. Financial support from the German Research Foundation (DFG) is gratefully acknowledged (Grant No. DFG BA 4967/1-2).

\section{References}

Alesina, A. and E. Spolaore (1997). On the number and size of nations. Quarterly Journal of Economics 112(4), 1027-1056.

Allers, M. A. and J. B. Geertsema (2014). The Effects of Local Government Amalgamation on Public Spending and Service Levels: Evidence from 15 Years of Municipal Boundary Reform. University of Groningen, Faculty of Economics and Business.

Amt für Statistik Berlin-Brandenburg (2013). Produkte, Lange Reihen. https://www.statistik-berlin-brandenburg.de/statistiken/inhalt-statistiken.asp (15.04.2013).

Angrist, J. D. and J.-S. Pischke (2009). Mostly harmless econometrics: an empiricist's companion. Princeton University Press. 
Blom-Hansen, J. (2010). Municipal amalgamations and common pool problems: the Danish local government reform in 2007. Scandinavian Political Studies 33, 51-73.

Blom-Hansen, J., K. Houlberg, and S. Serritzlew (2014). Size, democracy, and the economic costs of running the political system. American Journal of Political Science 58, 790-803.

Blume, L. and T. Blume (2007). The economic effects of local authority mergers: empirical evidence for German city regions. Annals of Regional Science 41, 689-713.

Brecht, A. (1932). Internationaler Vergleich der öffentlichen Ausgaben. Leipzig: Teubner.

Bruns, B., R. Freier, and A. Schumann (2015). Finding your right (or left) partner to merge. Technical report, Discussion Papers, Deutsches Institut für Wirtschaftsforschung.

Edwards, J. and M. Keen (1996). Tax competition and leviathan. European Economic Review 40, 113-134.

Fox, W. F. and T. Gurley (2006). Will consolidation improve sub-national governments? World Bank Working Paper No. 3919.

Fritz, B. (2013). Fiscal effects of municipal amalgamations: Evidence from a German state. Mimeo (Walter Eucken Institut).

Gordon, N. and B. Knight (2008). The effects of school district consolidation on educational cost and quality. Public Finance Review 36(4), 408-430.

Gordon, N. and B. Knight (2009). A spatial merger estimator with an application to school district consolidation. Journal of Public Economics 93(5), 752-765.

Gul, F. and W. Pesendorfer (2010). Strategic redistricting. The American Economic Review 100(4), 1616-1641. 
Hanes, N. (2015). Amalgamation impacts on local public expenditures in sweden. Local Government Studies 41(1), 63-77.

Hanes, N. and M. Wikström (2010). Amalgamation impacts on local growth: are voluntary municipal amalgamations more efficient than compulsory amalgamations. Canadian Journal of Regional Science (online) 33(1), 57-70.

Hansen, S. W. (2014). Common pool size and project size: an empirical test on expenditures using danish municipal mergers. Public choice 159(1-2), 3-21.

Hansen, S. W. (2015). The democratic costs of size: How increasing size affects citizen satisfaction with local government. Political Studies 63(2), 373-389.

Hansen, S. W., K. Houlberg, and L. H. Pedersen (2014). Do municipal mergers improve fiscal outcomes? Scandinavian Political Studies 37(2), 196-214.

Hinnerich, B. T. (2009). Do merging local governments free ride on their counterparts when facing boundary reform? Journal of Public Economics 93, 721-728.

Hyytinen, A., T. Saarimaa, and J. Tukiainen (2014). Electoral vulnerability and size of local governments: Evidence from voting on municipal mergers. Journal of Public Economics 120, 193-204.

Jordahl, H. and C. Y. Liang (2010). Merged municipalities, higher debt: on free-riding and the common pool problem. Public Choice 143, 157-172.

Kauder, B. (2014). Incorporation of municipalities and population growth: A propensity score matching approach. Papers in Regional Science.

Landesbetrieb für Datenverarbeitung und Statistik (2005). Beitrag zur Statistik 16: Gebiets- und Namensänderungen im Land Brandenburg von 1875-2004.

Landtag Brandenburg (1998). Gesetz zur Förderung freiwilliger Gemeindezusammenschlüsse, Drucksache 2/4905. 
Landtag Brandenburg (2000). Entschließung des Landtages Brandenburg: Starke Gemeinden für Brandenburg - Leitlinien der Landesregierung für die Entwicklung der Gemeindestruktur im Land Brandenburg, Drucksache 3/1732-B.

Landtag Brandenburg (2003). Gesetz- und Verordnungsblatt für das Land Brandenburg Teil I - Gesetze zur landesweiten Gemeindegebietsreform.

Landtag Brandenburg (2012). Zwischenbericht der Enquetekommission 5/2 "Kommunal - und Landesverwaltung - bürgernah, effektiv und zukunftsfest - Brandenburg 2020".

Lassen, D. D. and S. Serritzlew (2011a). Jurisdiction size and local democracy: Evidence on internal political efficacy from large-scale municipal reform. American Political Science Review 105(2), 238-258.

Lassen, D. D. and S. Serritzlew (2011b). Size and equal opportunity in the democratic process: The effect of the danish local government reform on inequality in internal political efficacy. World Political Science 7(1).

Lüchinger, S. and A. Stutzer (2002). Skalenerträge in der öffentlichen Kernverwaltung: eine empirische Analyse anhand von Gemeindefusionen. Swiss Political Science Review 8, 27-50.

Ministerium des Innern Brandenburg (2001). Starke Gemeinden für Brandenburg - Das neue Gemeindereformgesetz, Infobroschüre.

Ministerium des Innern Brandenburg (2011). Bericht zur Evaluierung der Gemeindegebietsreform 2003.

Moisio, A. and R. Uusitalo (2013). The impact of municipality mergers on local public expenditures in Finland. Public Finance and Management 13, 148-166.

Nakazawa, K. (2013). Amalgamation, free-ride behavior, and regulation. Technical report, Joint Discussion Paper Series in Economics. 
Nelson, M. A. (1992). Municipal amalgamation and the growth of the local public sector in Sweden. Journal of Regional science 32(1), 39-53.

Niskanen, W. A. (1968). The peculiar economics of bureaucracy. American Economic Review 58(2), 293-305.

Oates, W. (1972). Fiscal federalism. New York: Harcourt Brace Jovanovich.

Oates, W. E. (2005). Towards a second generation theory of fiscal federalism. International Tax and Public Finance 12, 349-373.

Reingewertz, Y. (2012). Do municipal amalgamations work? Evidence from municipalities in Israel. Journal of Urban Economics 72, 240-251.

Reiter, M. and A. Weichenrieder (1997). Are public goods public? A critical survey of the demand estimates for local public services. FinanzArchiv/Public Finance Analysis, $374-408$.

Saarimaa, T. and J. Tukiainen (2014). I don't care to belong to any club that will have me as a member: empirical analysis of municipal mergers. Political Science Research and Methods 2(01), 97-117.

Saarimaa, T. and J. Tukiainen (2015). Common pool problems in voluntary municipal mergers. European Journal of Political Economy 38, 140-152.

Sørensen, R. J. (2006). Local government consolidations: The impact of political transaction costs. Public Choice 127(1-2), 75-95.

Statistisches Bundesamt (2013). Zahlen \& Fakten, Länder \& Regionen, Regionales, Administrative Gebietsgliederungen: Gemeinden in Deutschland nach Bevölkerung am 31.12.2011 auf Grundlage des Zensus 2011 und früherer Zählungen. https://www.destatis.de/DE/ZahlenFakten/LaenderRegionen/Regionales/ Gemeindeverzeichnis/Administrativ/AdministrativeUebersicht.html (20.06.2013). 
Verfassungsgericht Brandenburg (2006). Gemeindegebietsreform: Alle Verfahren abgeschlossen. http://www.verfassungsgericht.brandenburg.de/cms/detail. php/bb1.c.176969.de (20.06.2013).

Weese, E. (2015). Political mergers as coalition formation: An analysis of the Heisei municipal amalgamations. Quantitative Economics forthcoming.

Zimmermann, H. (1999). Kommunalfinanzen - Eine Einführung in die finanzwissenschaftliche Analyse der kommunalen Finanzwirtschaft. Baden-Baden: Berliner Wissenschaftsverlag. 
Table 1: Summary Statistics

\begin{tabular}{|c|c|c|c|c|c|c|}
\hline Variable & & Mean & Std. & Min. & Max. & Obs. \\
\hline \multirow[t]{3}{*}{ Amalgamation } & overall & 0.626 & 0.484 & 0.000 & 1.000 & 6249 \\
\hline & between & & 0.484 & 0.000 & 1.000 & 409 \\
\hline & within & & 0.000 & 0.626 & 0.626 & 15.279 \\
\hline \multirow[t]{3}{*}{ Voluntary } & overall & 0.394 & 0.489 & 0.000 & 1.000 & 6249 \\
\hline & between & & 0.490 & 0.000 & 1.000 & 409 \\
\hline & within & & 0.000 & 0.394 & 0.394 & 15.279 \\
\hline \multirow{3}{*}{ Compulsory } & overall & 0.232 & 0.422 & 0.000 & 1.000 & 6249 \\
\hline & between & & 0.423 & 0.000 & 1.000 & 409 \\
\hline & within & & 0.000 & 0.232 & 0.232 & 15.279 \\
\hline \multirow[t]{3}{*}{ Participants } & overall & 3.051 & 3.810 & 0.000 & 22.000 & 6249 \\
\hline & between & & 3.829 & 0.000 & 22.000 & 409 \\
\hline & within & & 0.000 & 3.051 & 3.051 & 15.279 \\
\hline \multirow[t]{3}{*}{ Annexation } & overall & 0.232 & 0.422 & 0.000 & 1.000 & 6249 \\
\hline & between & & 0.423 & 0.000 & 1.000 & 409 \\
\hline & within & & 0.000 & 0.232 & 0.232 & 15.279 \\
\hline \multirow{3}{*}{ Total expenditures } & overall & 1442.245 & 1088.088 & 535.547 & 37130.190 & 6249 \\
\hline & between & & 644.282 & 816.951 & 10658.050 & 409 \\
\hline & within & & 869.143 & -8161.140 & 32091.010 & 15.279 \\
\hline \multirow[t]{3}{*}{ Staff expenditures } & overall & 217.839 & 150.980 & 0.000 & 781.692 & 6249 \\
\hline & between & & 138.078 & 0.098 & 554.849 & 409 \\
\hline & within & & 60.866 & -59.501 & 758.569 & 15.279 \\
\hline \multirow[t]{3}{*}{ Administrative expenditures } & overall & 124.768 & 73.938 & 8.522 & 983.505 & 6249 \\
\hline & between & & 55.501 & 24.965 & 381.866 & 409 \\
\hline & within & & 49.143 & -82.902 & 916.131 & 15.279 \\
\hline \multirow[t]{3}{*}{ Current expenditures } & overall & 1003.716 & 721.723 & 401.295 & 23439.870 & 6249 \\
\hline & between & & 443.554 & 572.740 & 7049.120 & 409 \\
\hline & within & & 563.875 & -5207.385 & 20011.310 & 15.279 \\
\hline \multirow{3}{*}{ Total revenues } & overall & 1301.559 & 731.057 & -15.114 & 23642.040 & 6249 \\
\hline & between & & 434.881 & 765.033 & 7104.007 & 409 \\
\hline & within & & 583.295 & -4784.032 & 21317.350 & 15.279 \\
\hline \multirow{3}{*}{ Tax revenues } & overall & 292.269 & 605.804 & -16677.210 & 18423.190 & 6249 \\
\hline & between & & 308.661 & 137.371 & 5612.650 & 409 \\
\hline & within & & 517.974 & -17342.330 & 17758.060 & 15.279 \\
\hline \multirow{3}{*}{ Fiscal pressure } & overall & -2.488 & 276.207 & -9008.751 & 7019.375 & 6249 \\
\hline & between & & 102.746 & -1082.789 & 932.586 & 409 \\
\hline & within & & 255.899 & -8317.759 & 6084.301 & 15.279 \\
\hline \multirow{3}{*}{ Debt } & overall & 719.163 & 860.308 & 0.362 & 14666.670 & 5609 \\
\hline & between & & 765.406 & 11.648 & 8476.816 & 392 \\
\hline & within & & 368.328 & -3384.436 & 10863.360 & 14.309 \\
\hline \multirow[t]{3}{*}{ Population } & overall & 4991.444 & 7149.733 & 378.000 & 49371.000 & 6249 \\
\hline & between & & 7168.267 & 413.667 & 43810.630 & 409 \\
\hline & within & & 784.496 & -5087.156 & 13770.380 & 15.279 \\
\hline \multirow[t]{3}{*}{ Population density } & overall & 109.217 & 218.630 & 8.000 & 2393.000 & 6249 \\
\hline & between & & 216.722 & 8.905 & 2057.570 & 409 \\
\hline & within & & 33.791 & -683.805 & 699.195 & 15.279 \\
\hline Old & overall & 0.154 & 0.138 & 0.002 & 0.656 & 6249 \\
\hline & between & & 0.133 & 0.005 & 0.559 & 409 \\
\hline & within & & 0.037 & -0.100 & 0.406 & 15.279 \\
\hline Grants & overall & 335.045 & 70.842 & 0.000 & 712.694 & 6249 \\
\hline & between & & 51.944 & 52.700 & 429.285 & 409 \\
\hline & within & & 48.245 & -23.257 & 700.253 & 15.279 \\
\hline Income tax share & overall & 98.495 & 46.434 & 16.992 & 375.114 & 6249 \\
\hline & between & & 20.956 & 56.097 & 171.366 & 409 \\
\hline & within & & 41.398 & -25.819 & 319.688 & 15.279 \\
\hline Amalgamation grants & overall & 2.511 & 16.014 & 0.000 & 167.439 & 6249 \\
\hline & between & & 3.447 & 0.000 & 14.869 & 409 \\
\hline & within & & 15.652 & -12.358 & 158.788 & 15.279 \\
\hline Left & overall & 0.235 & 0.215 & 0.000 & 1.000 & 6249 \\
\hline & between & & 0.198 & 0.000 & 0.930 & 409 \\
\hline & within & & 0.083 & -0.232 & 0.635 & 15.279 \\
\hline
\end{tabular}




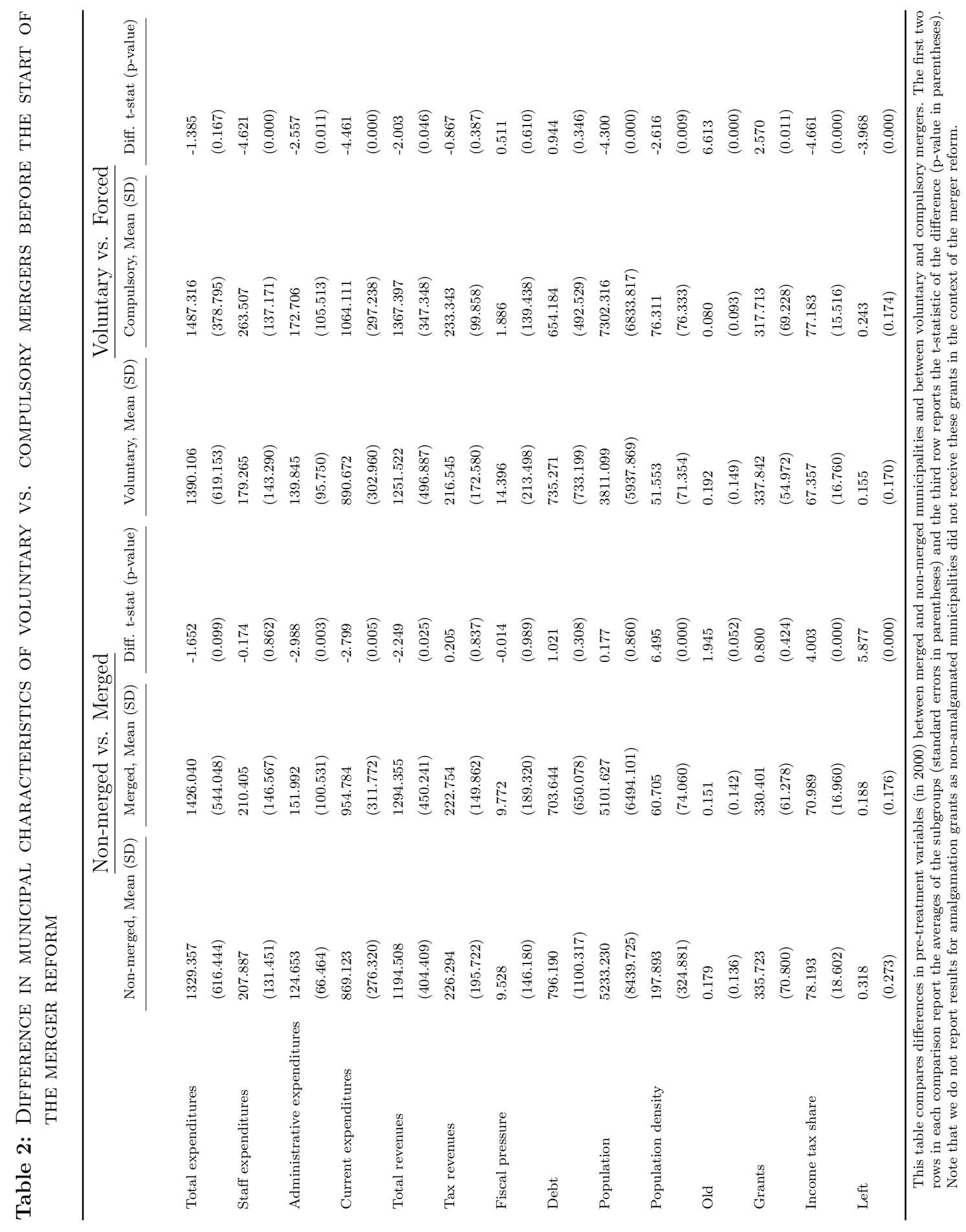




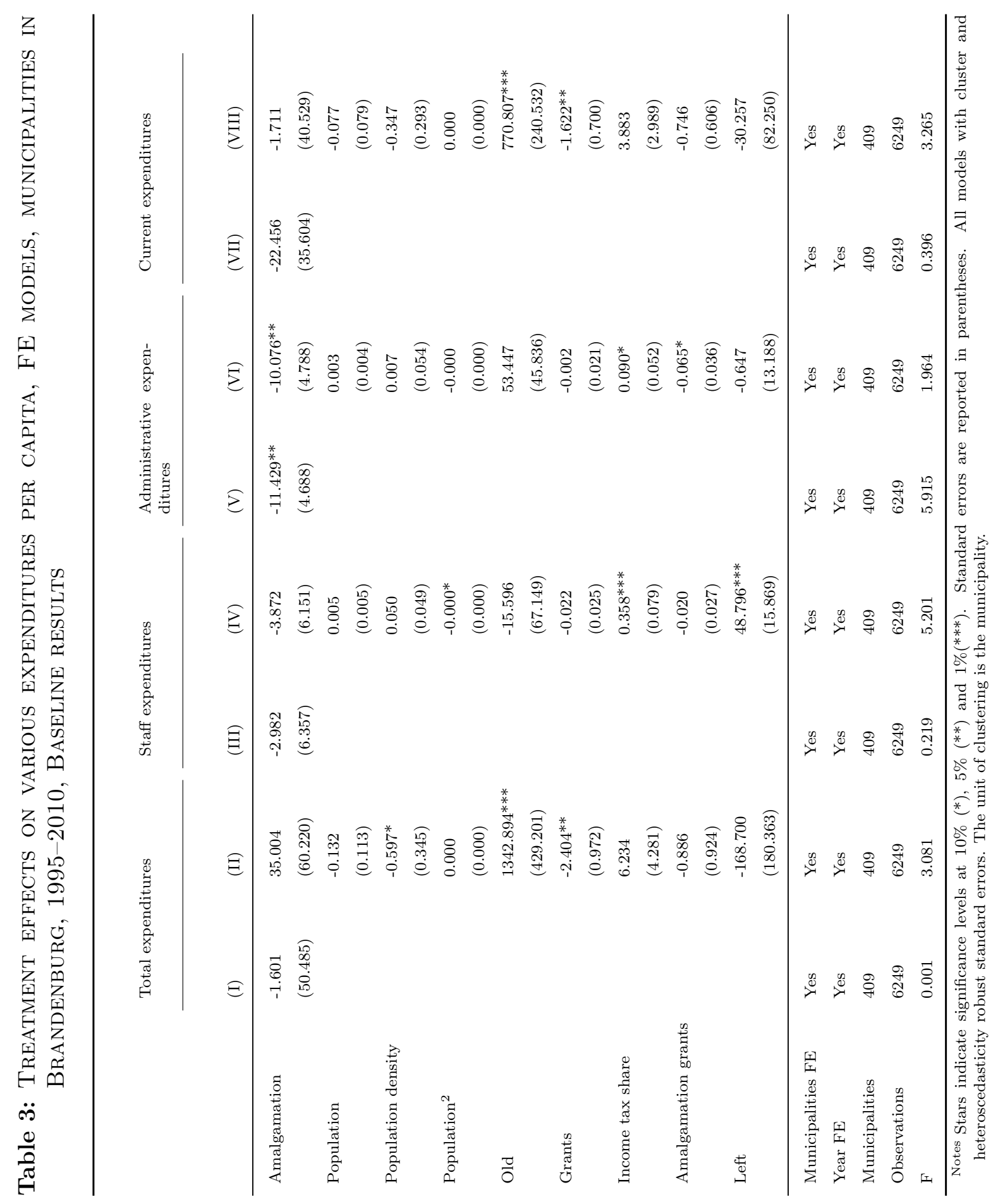




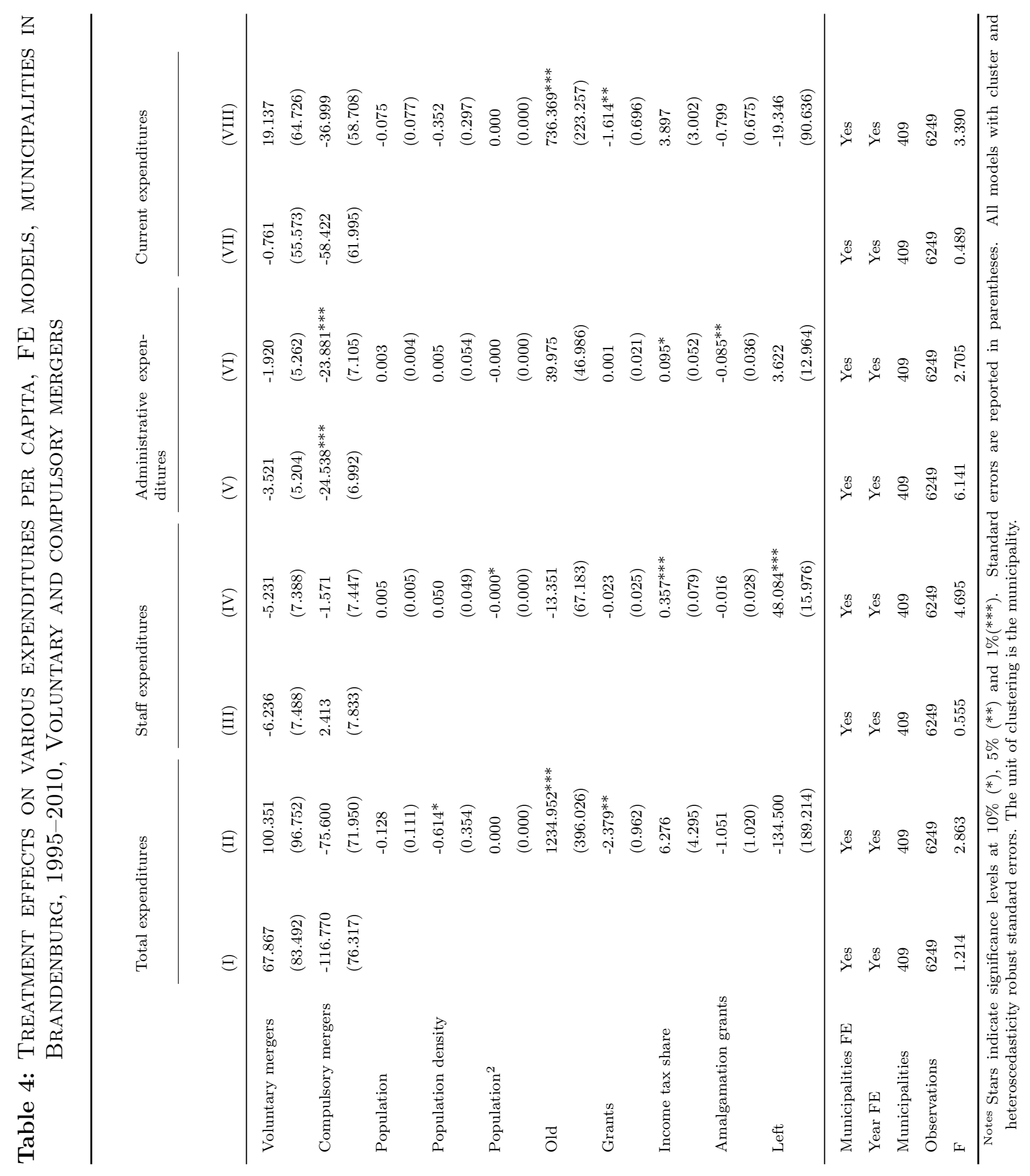




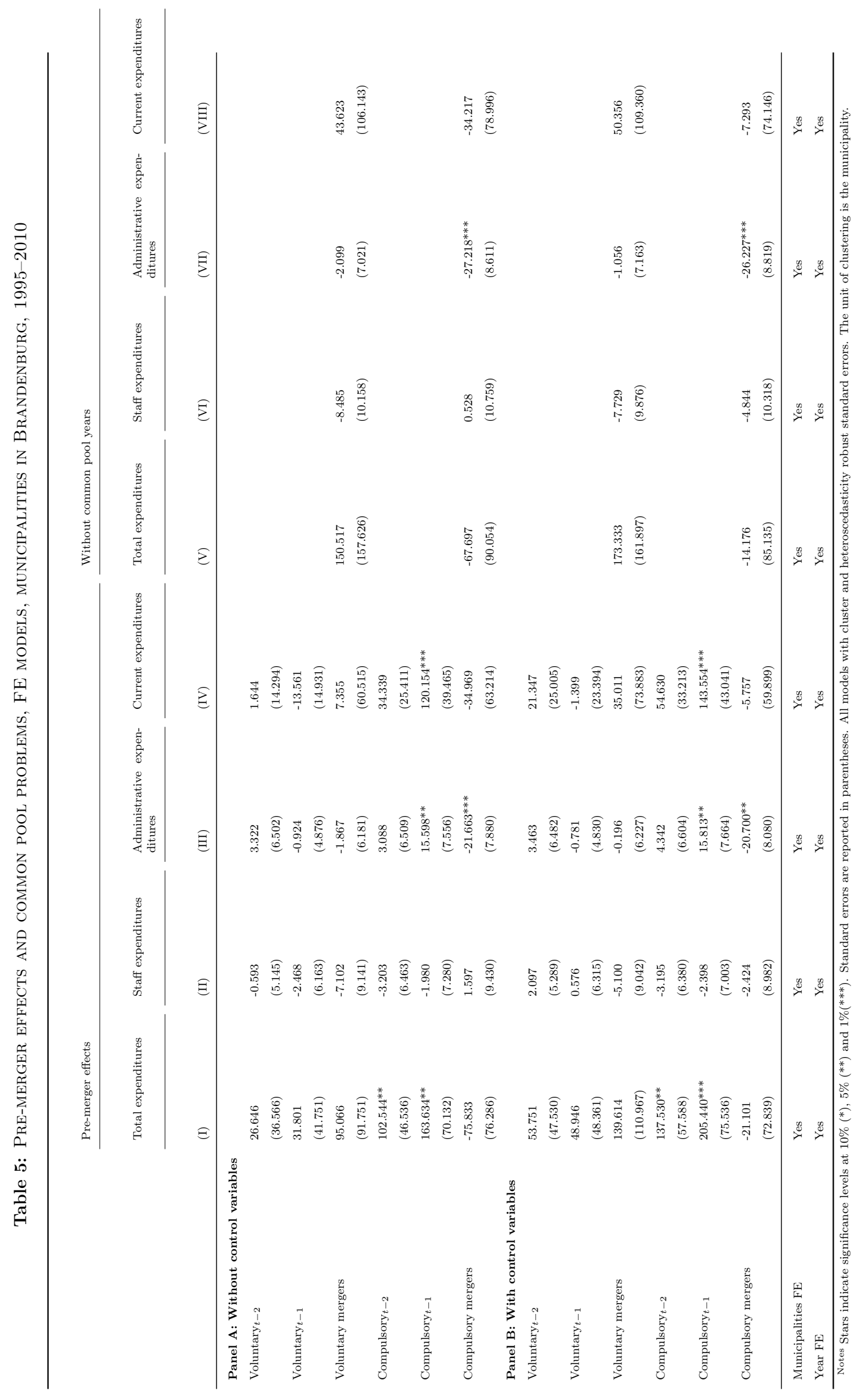




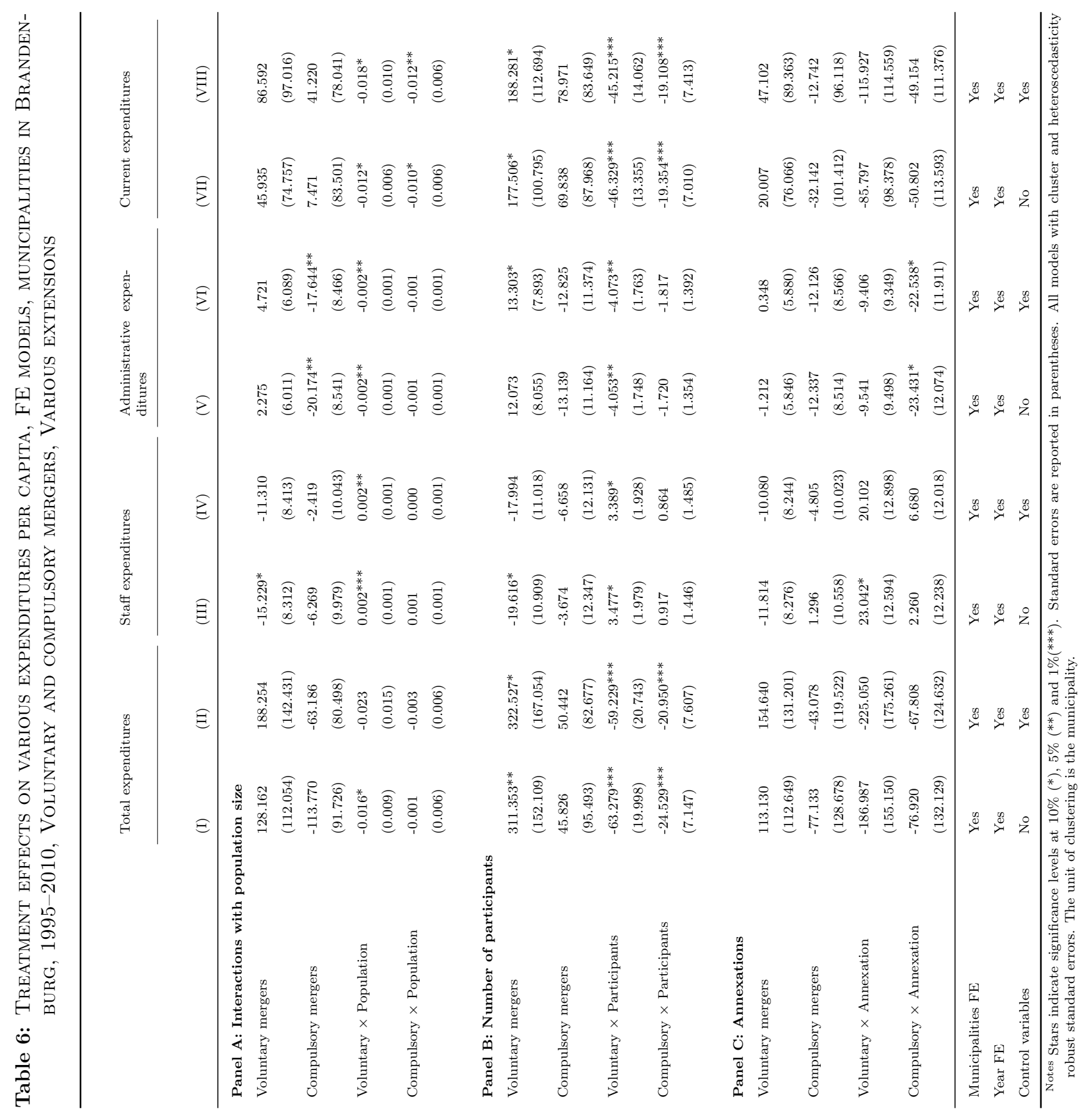




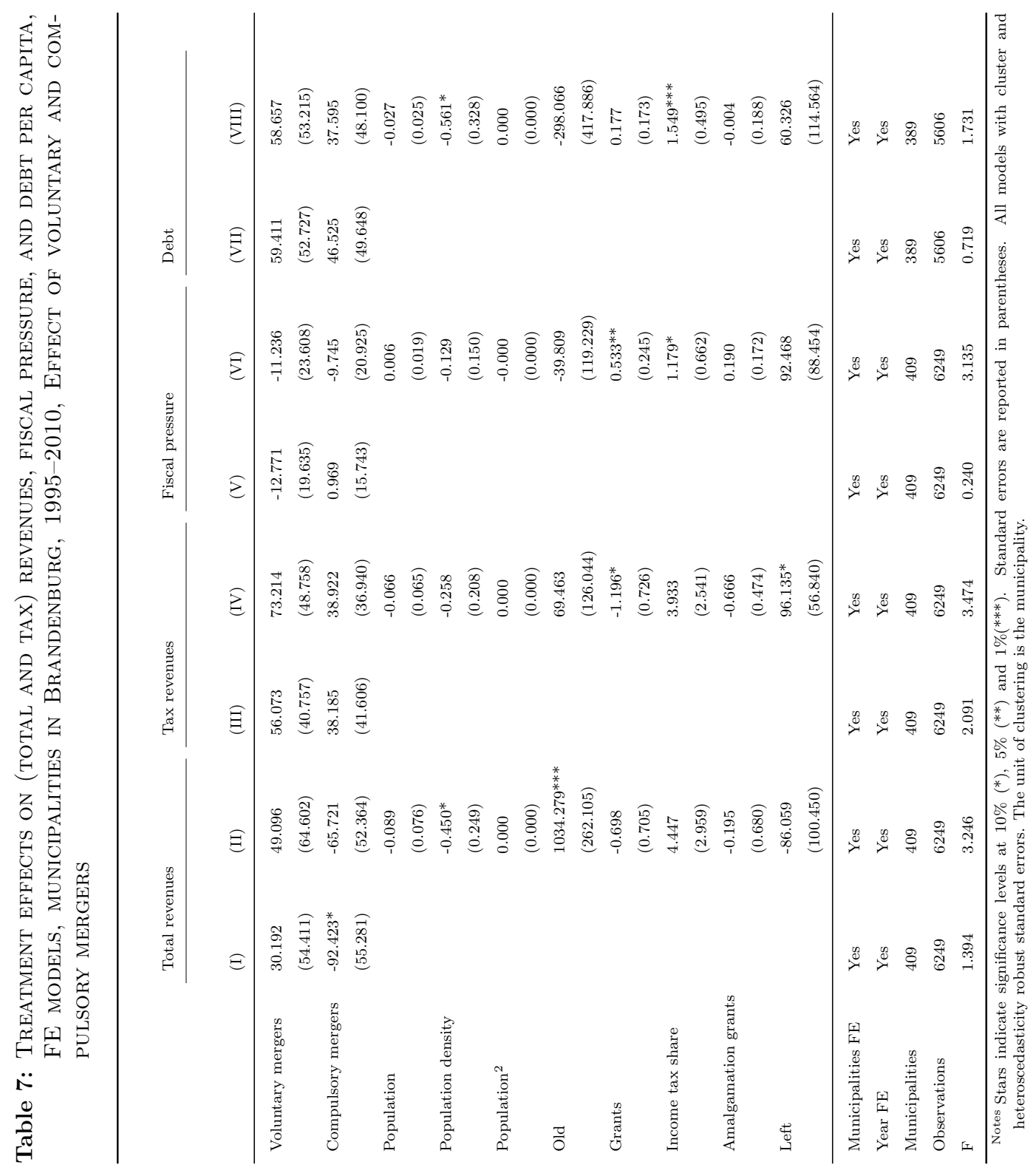




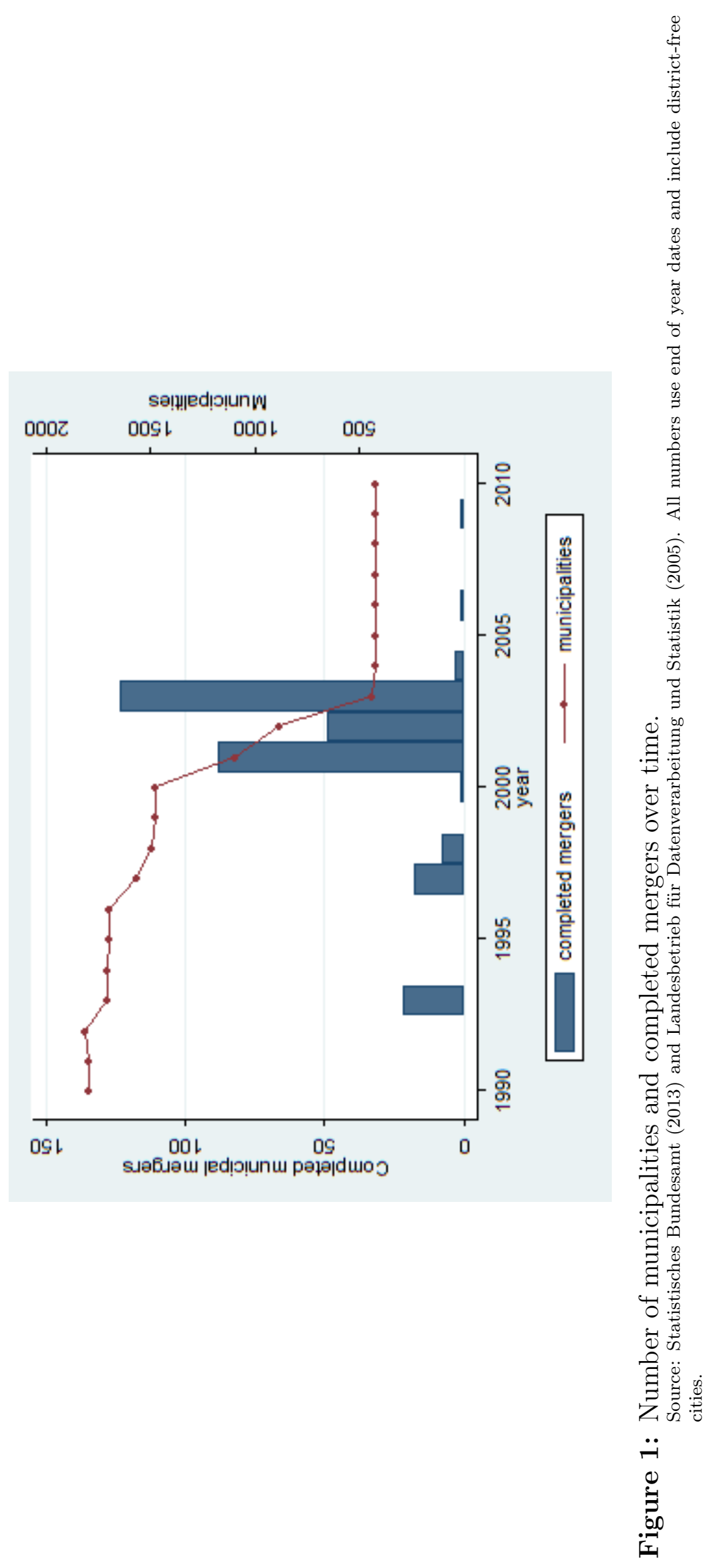



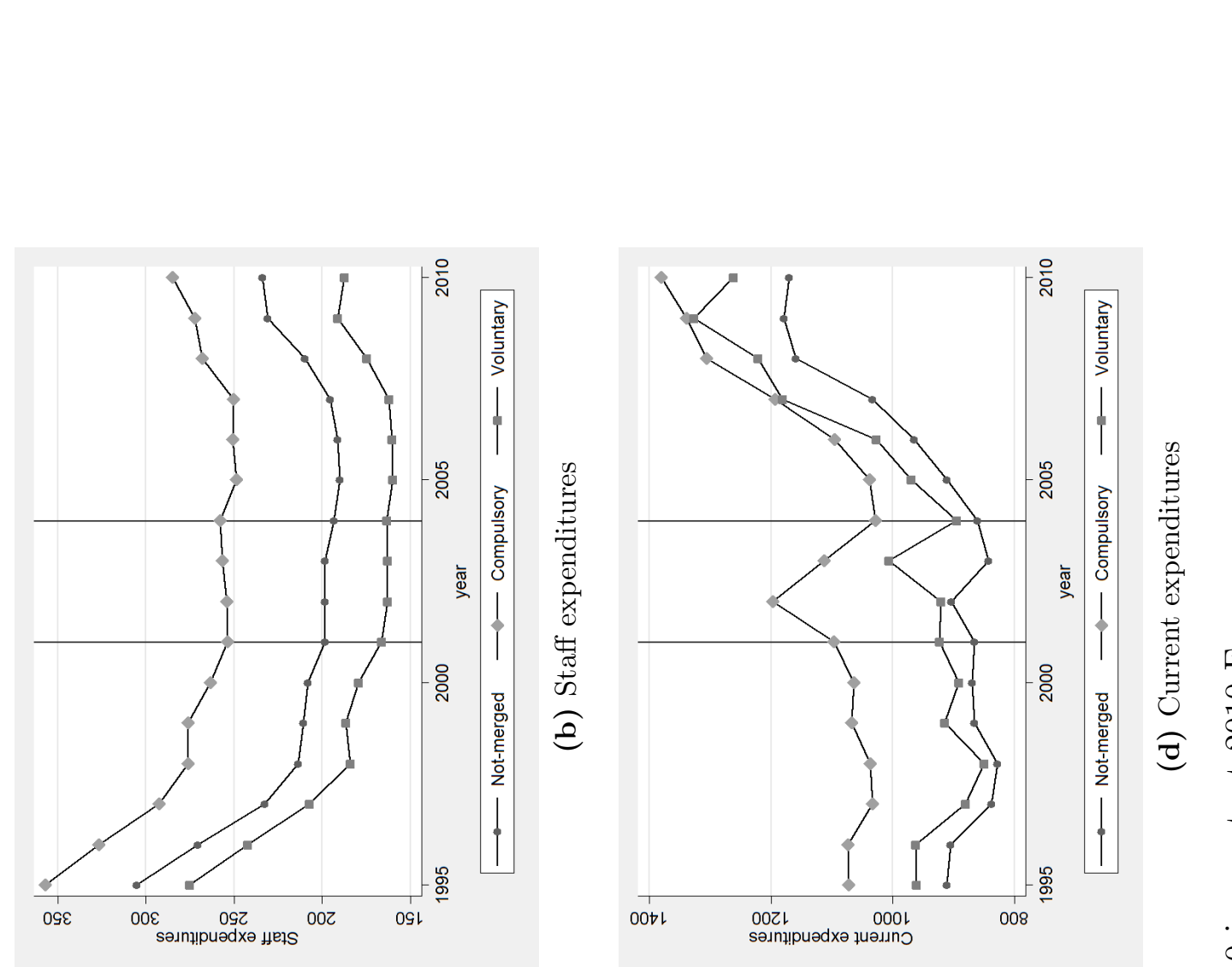

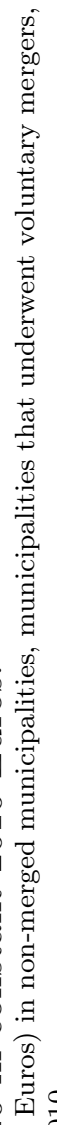
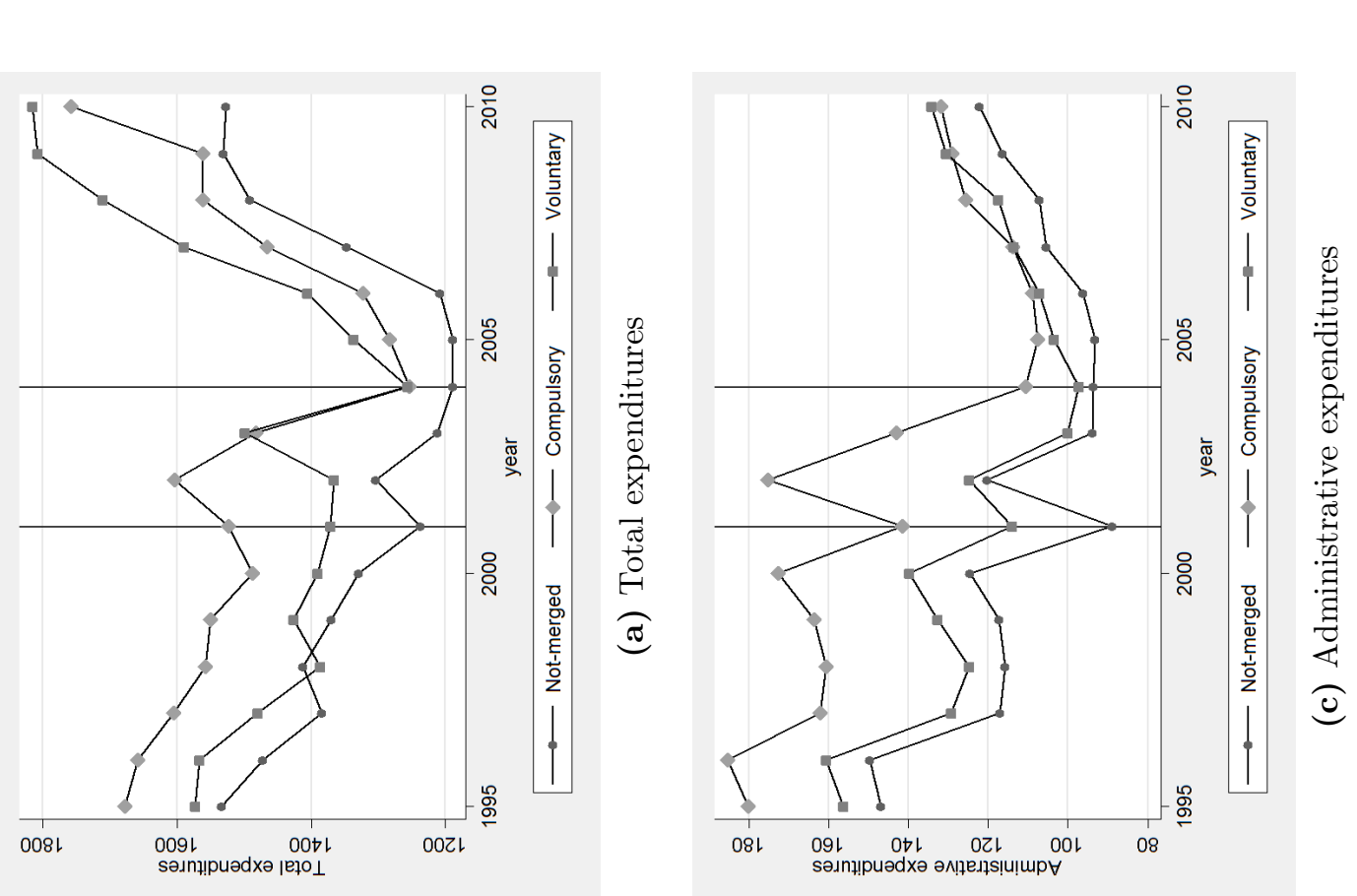

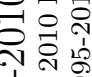

เ

需

एक

ఫึ

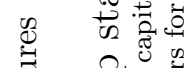

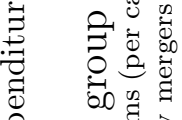

家家

.

क्षे

ن

,

记

击要

d

为的

도을

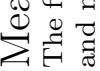

$\ddot{\sim}$

茫 


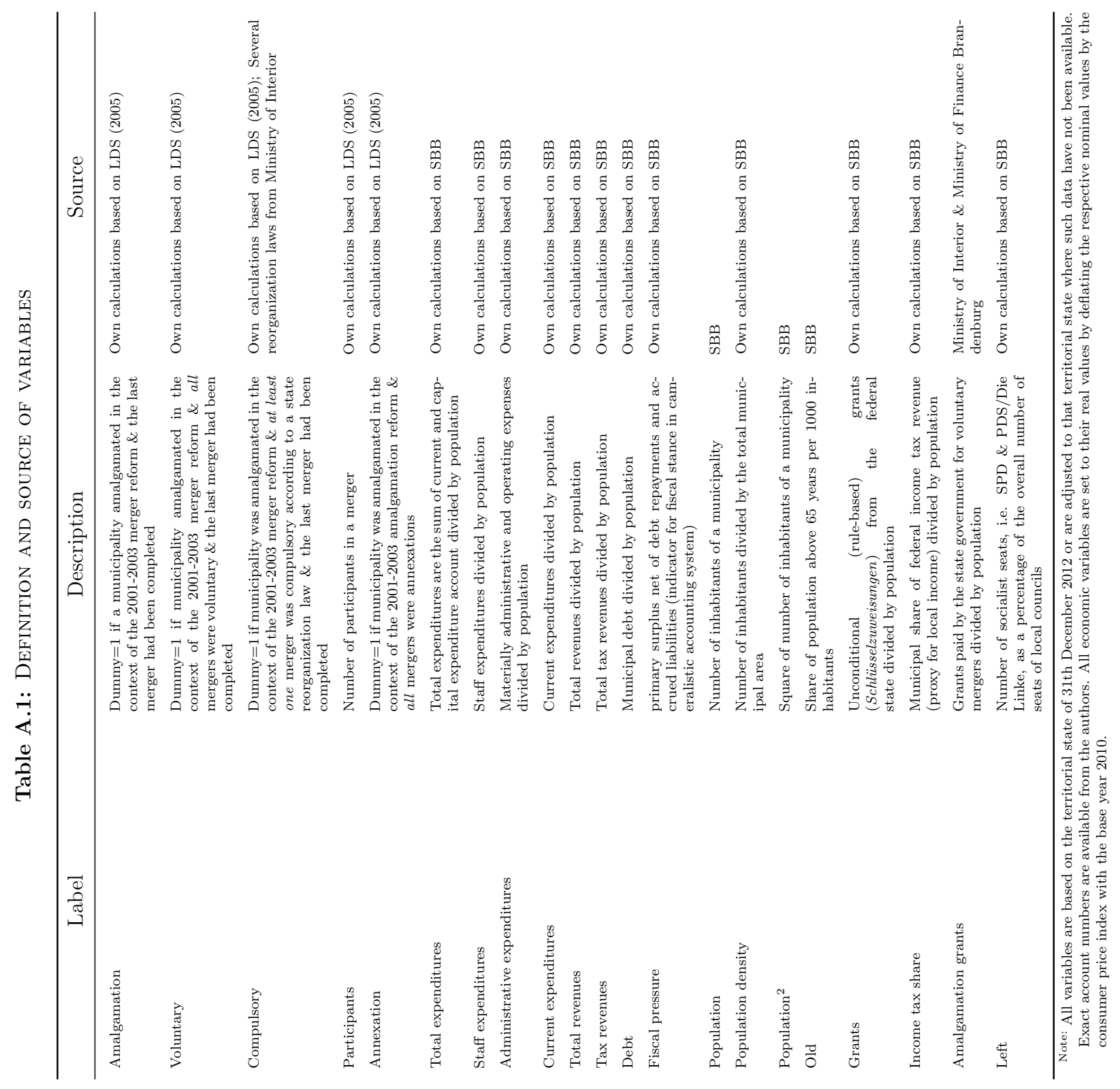




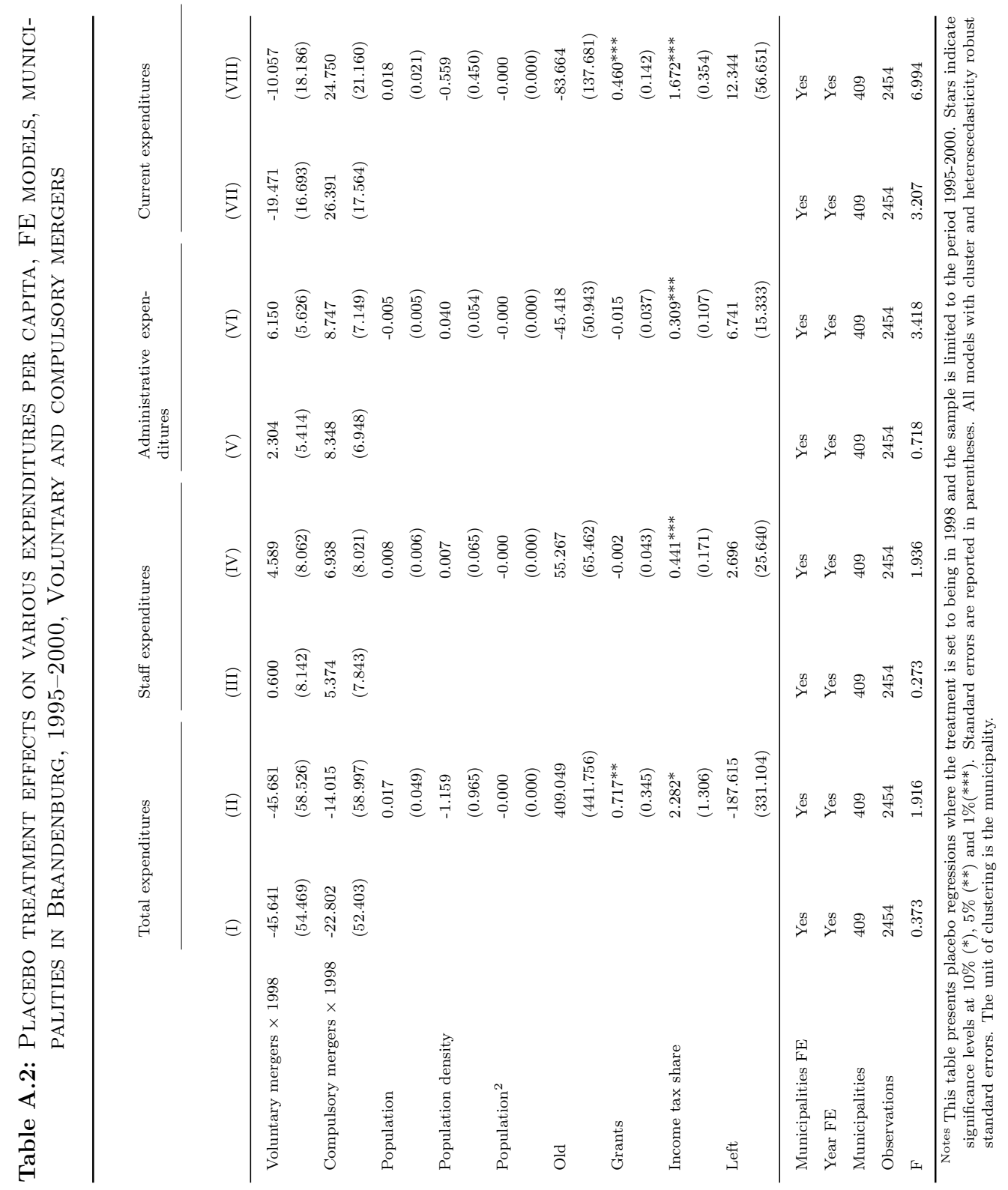




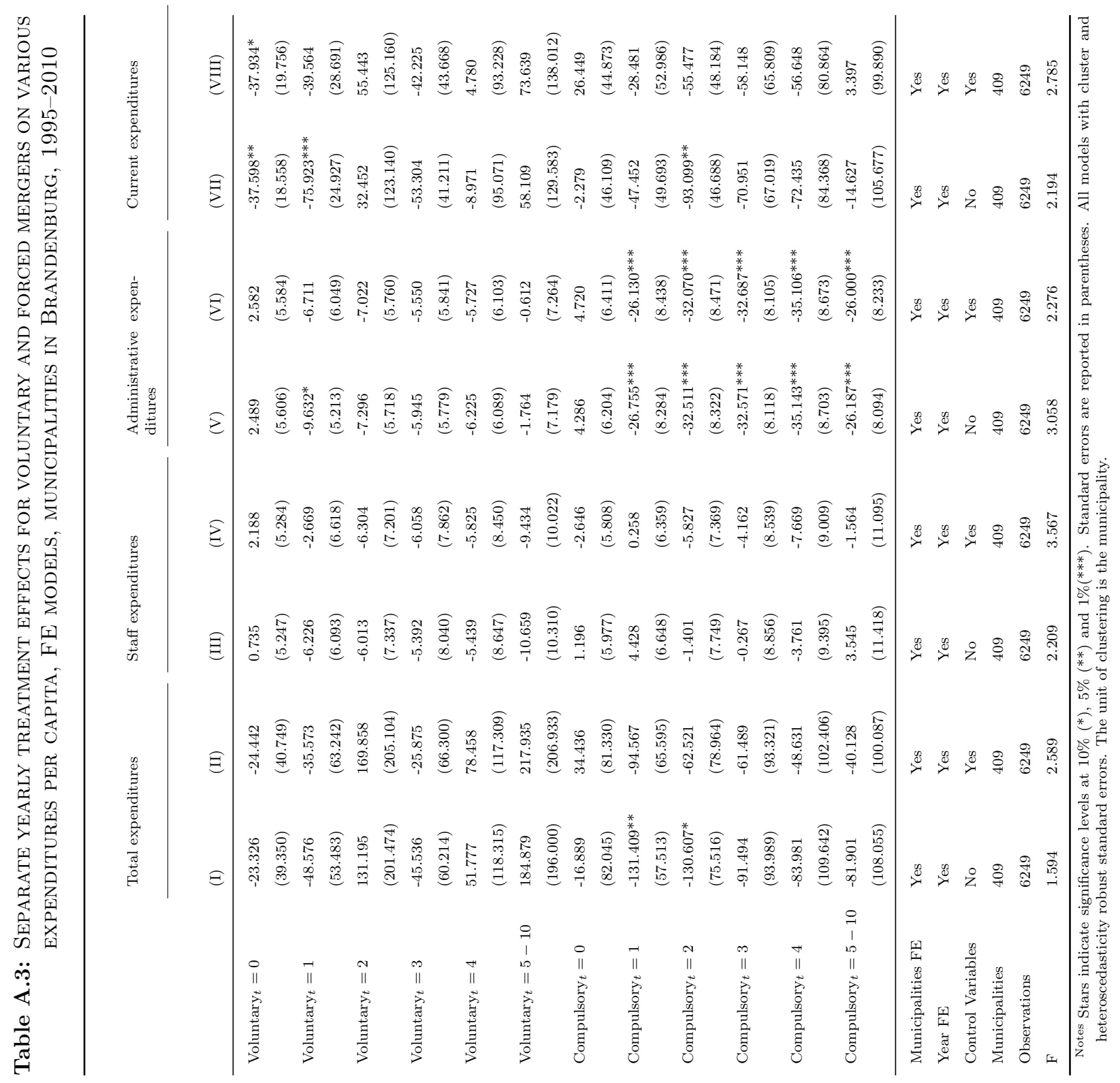




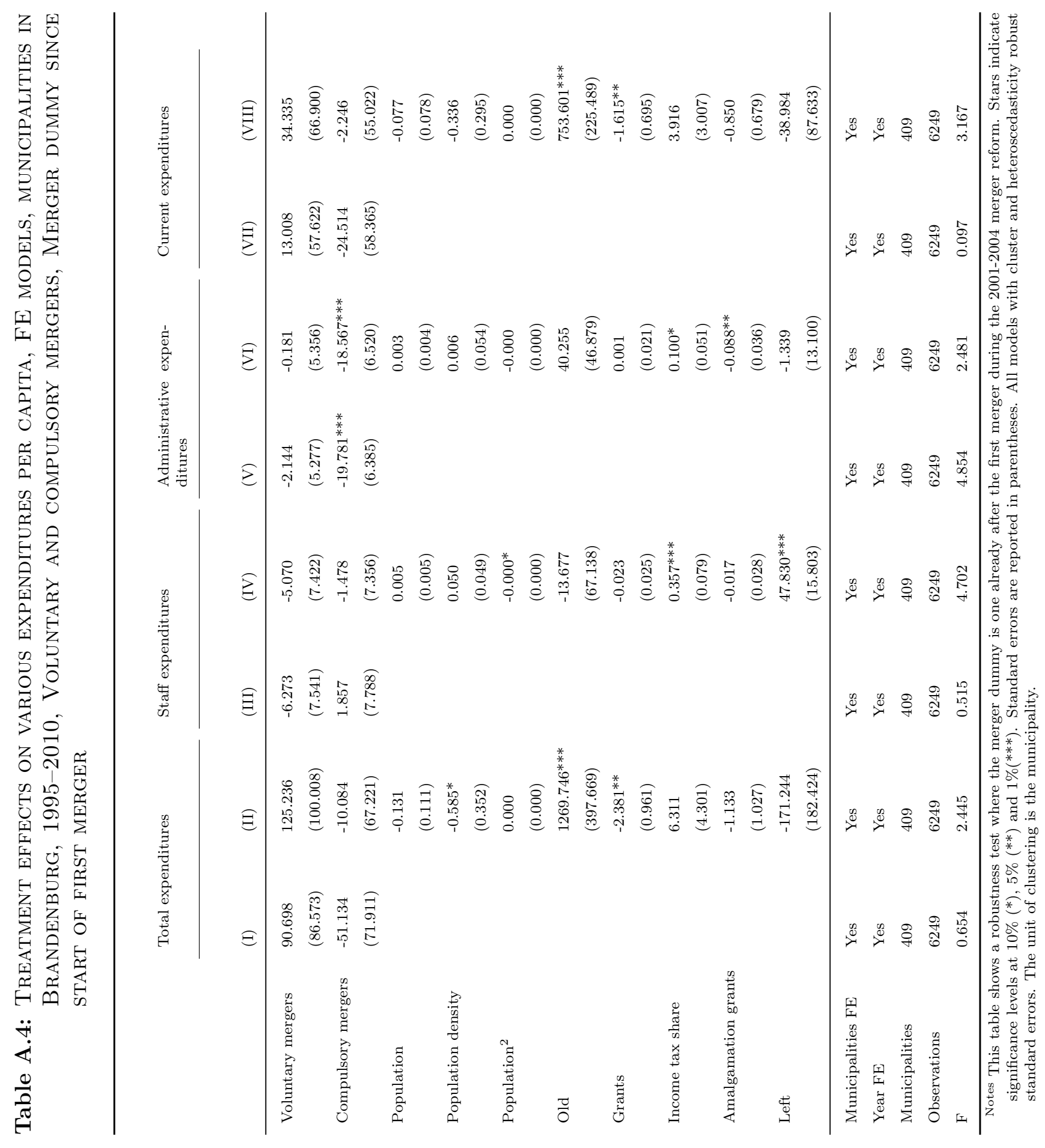




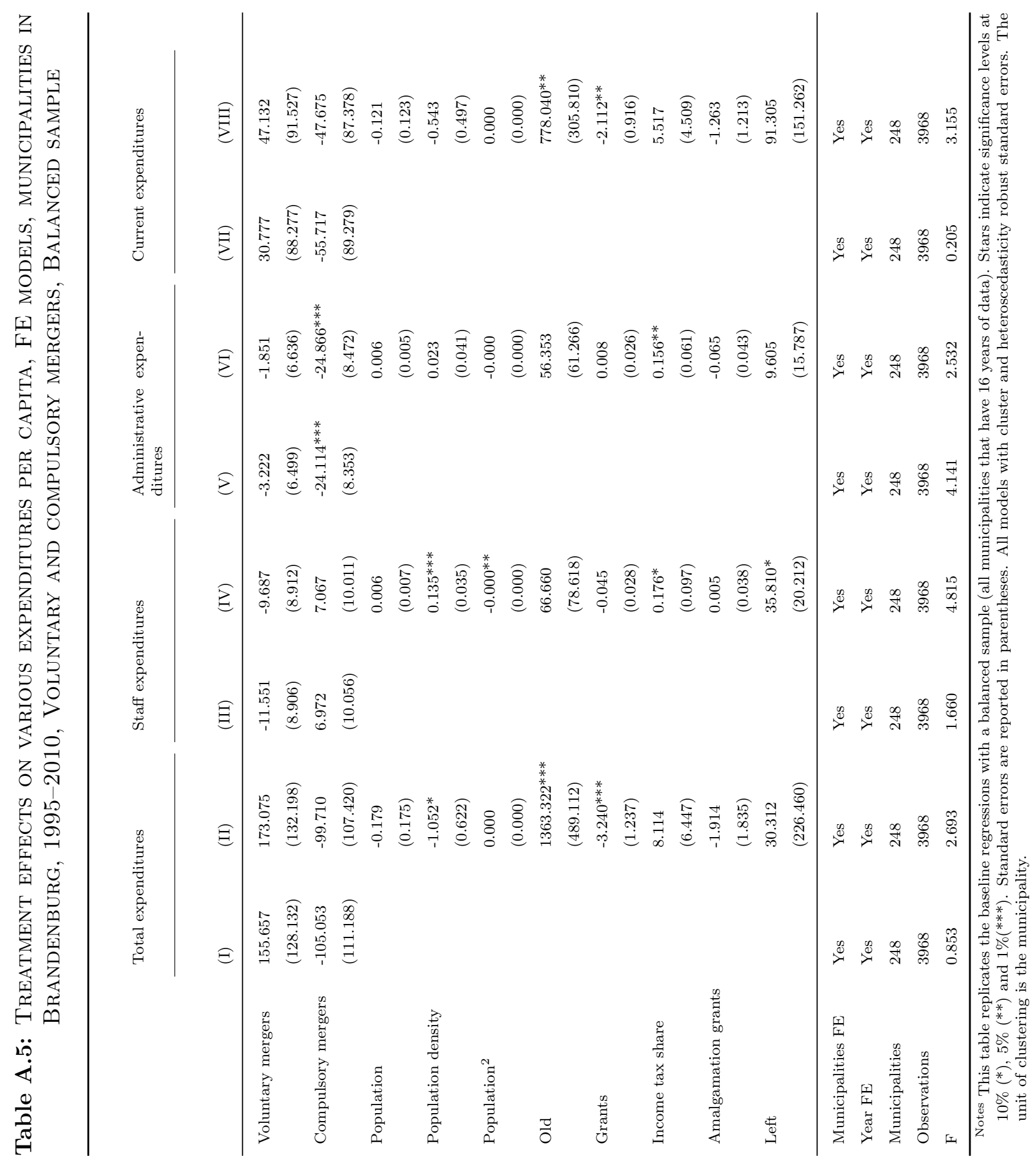




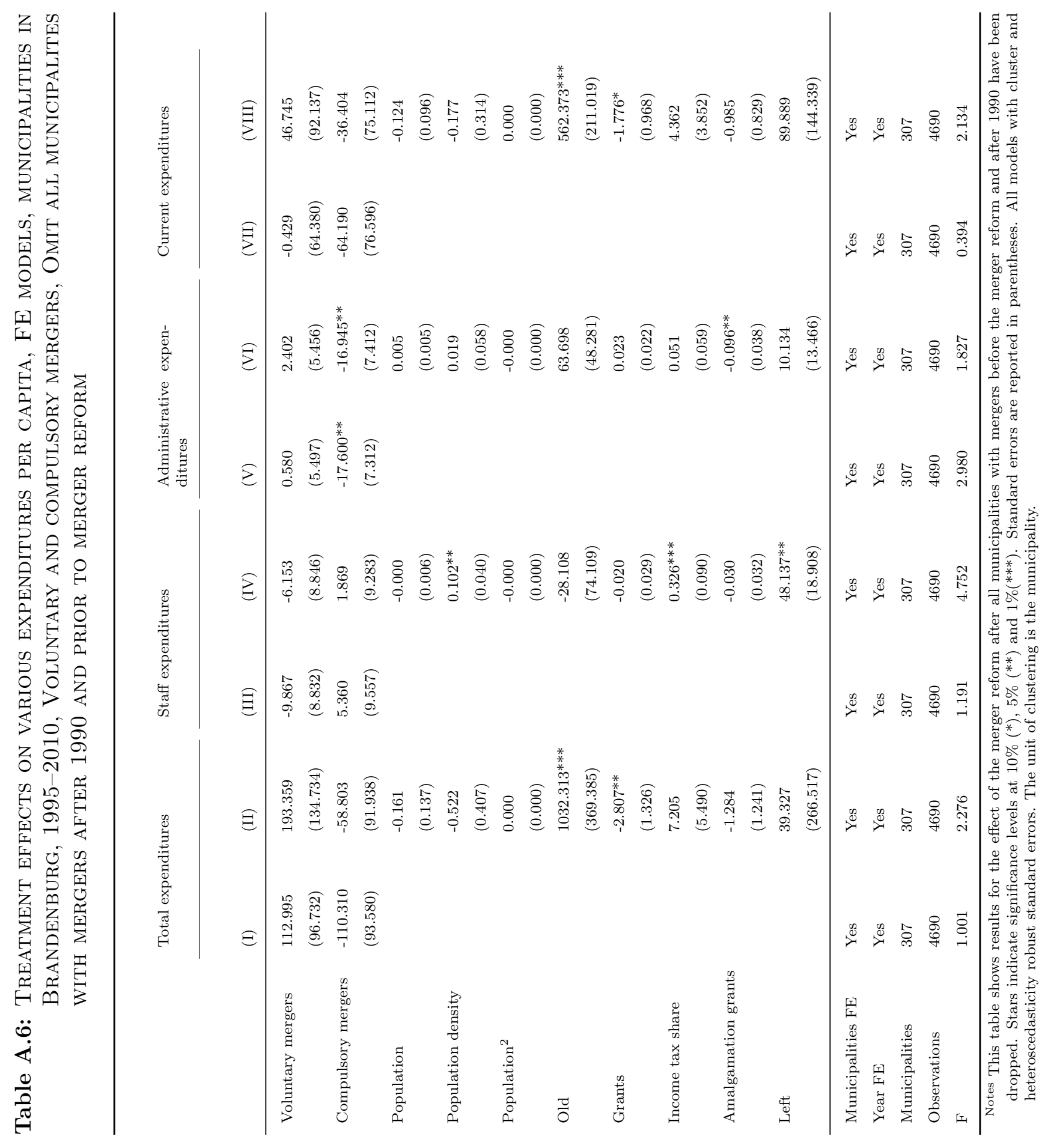




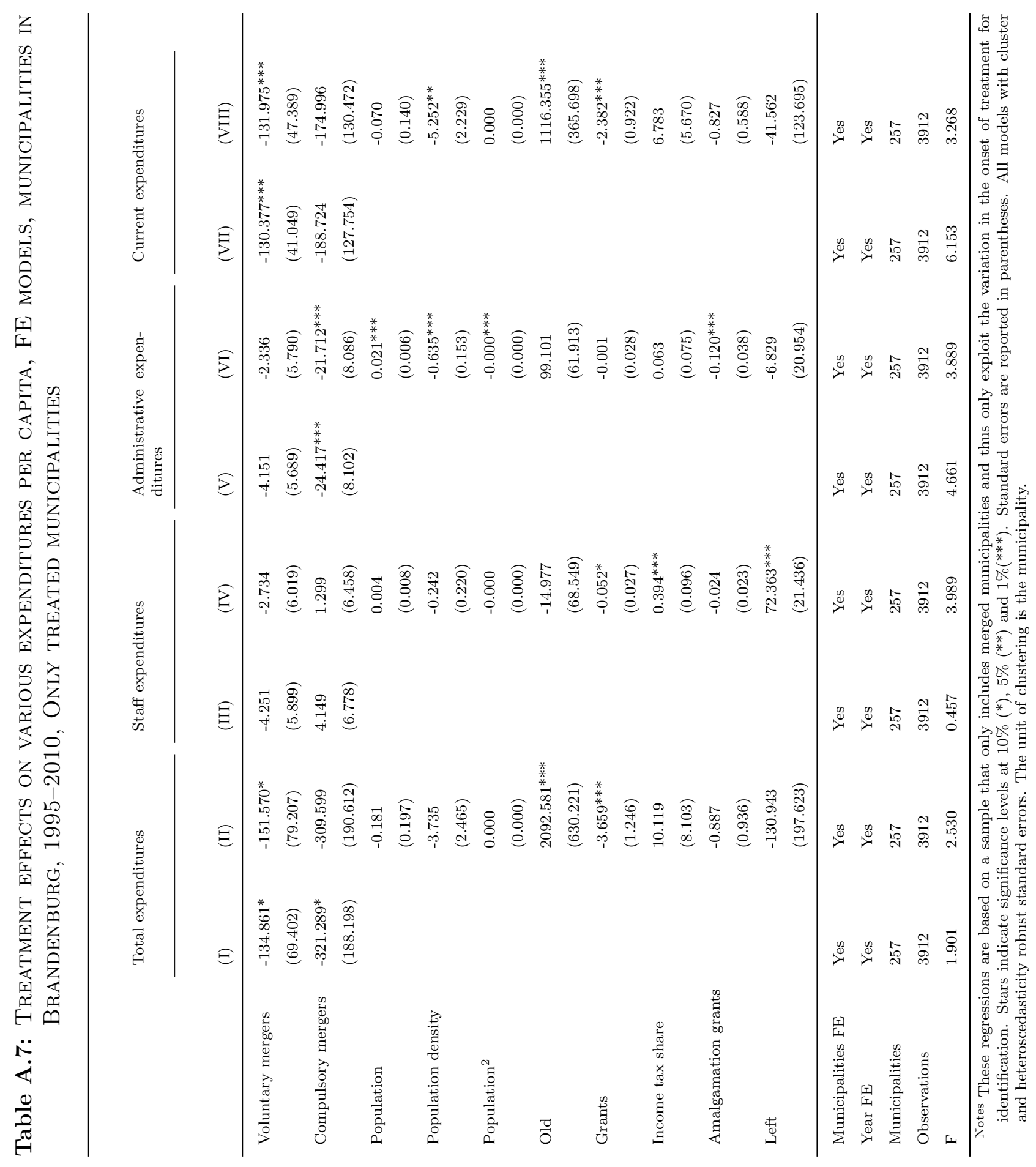




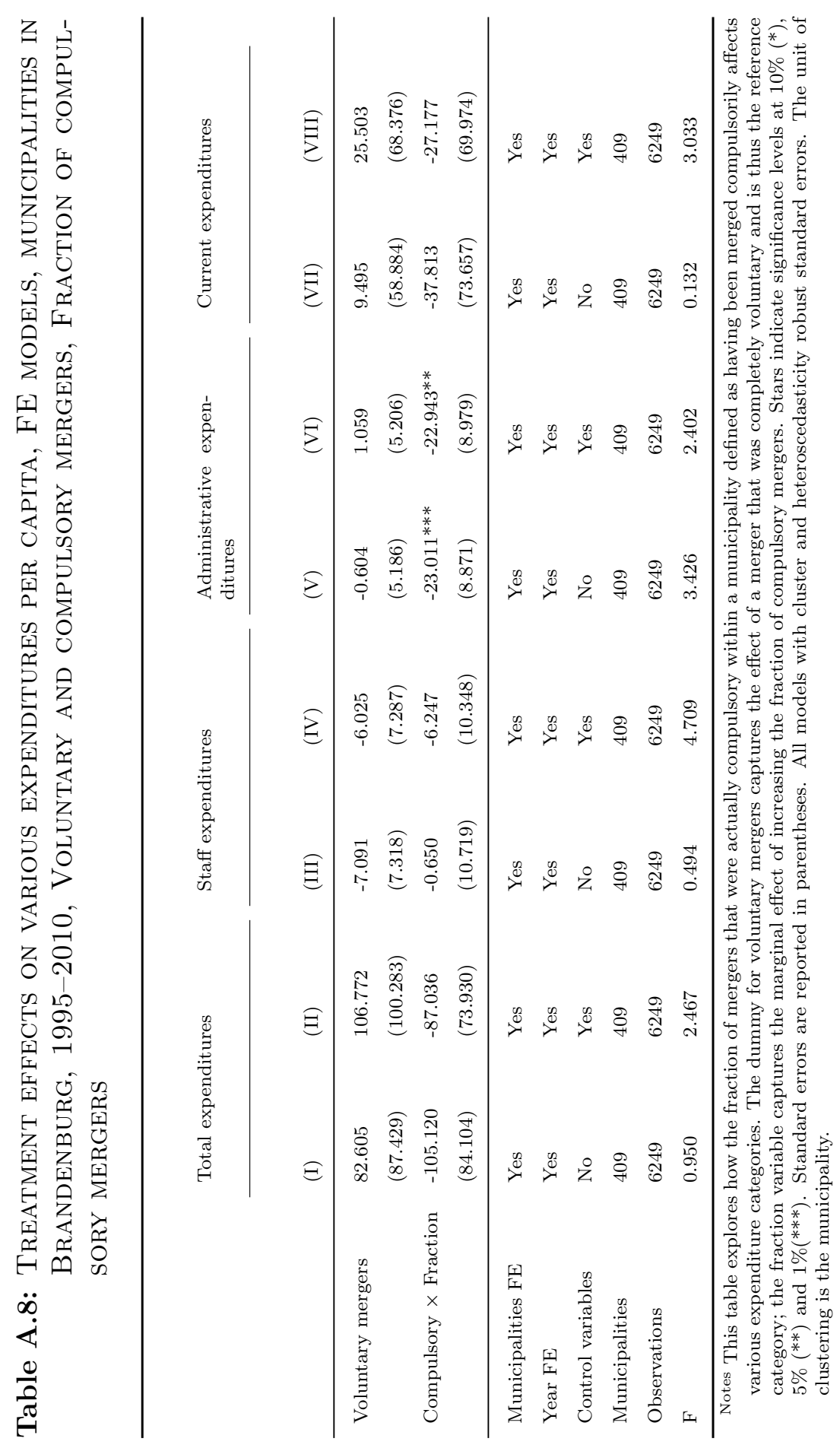




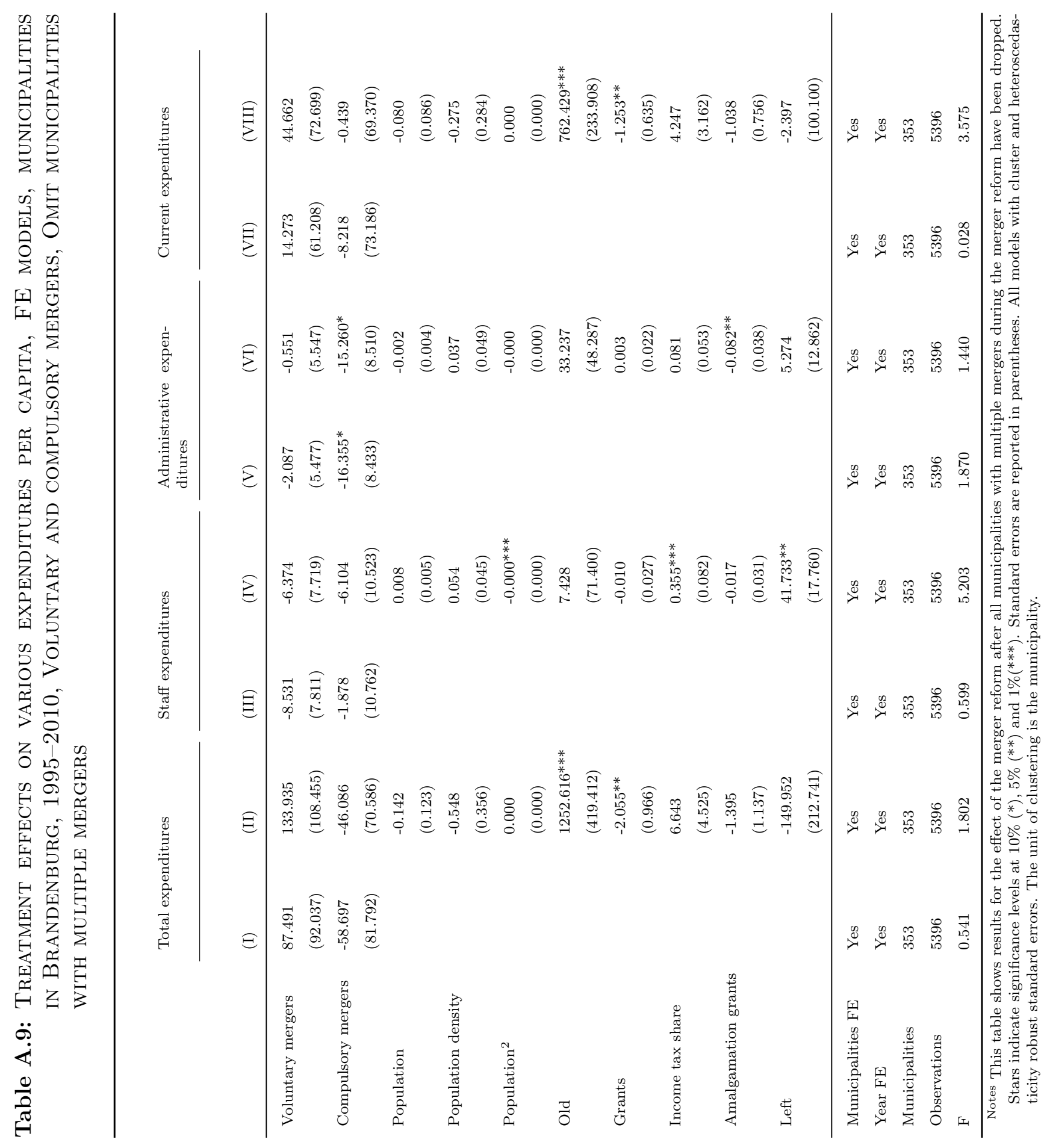




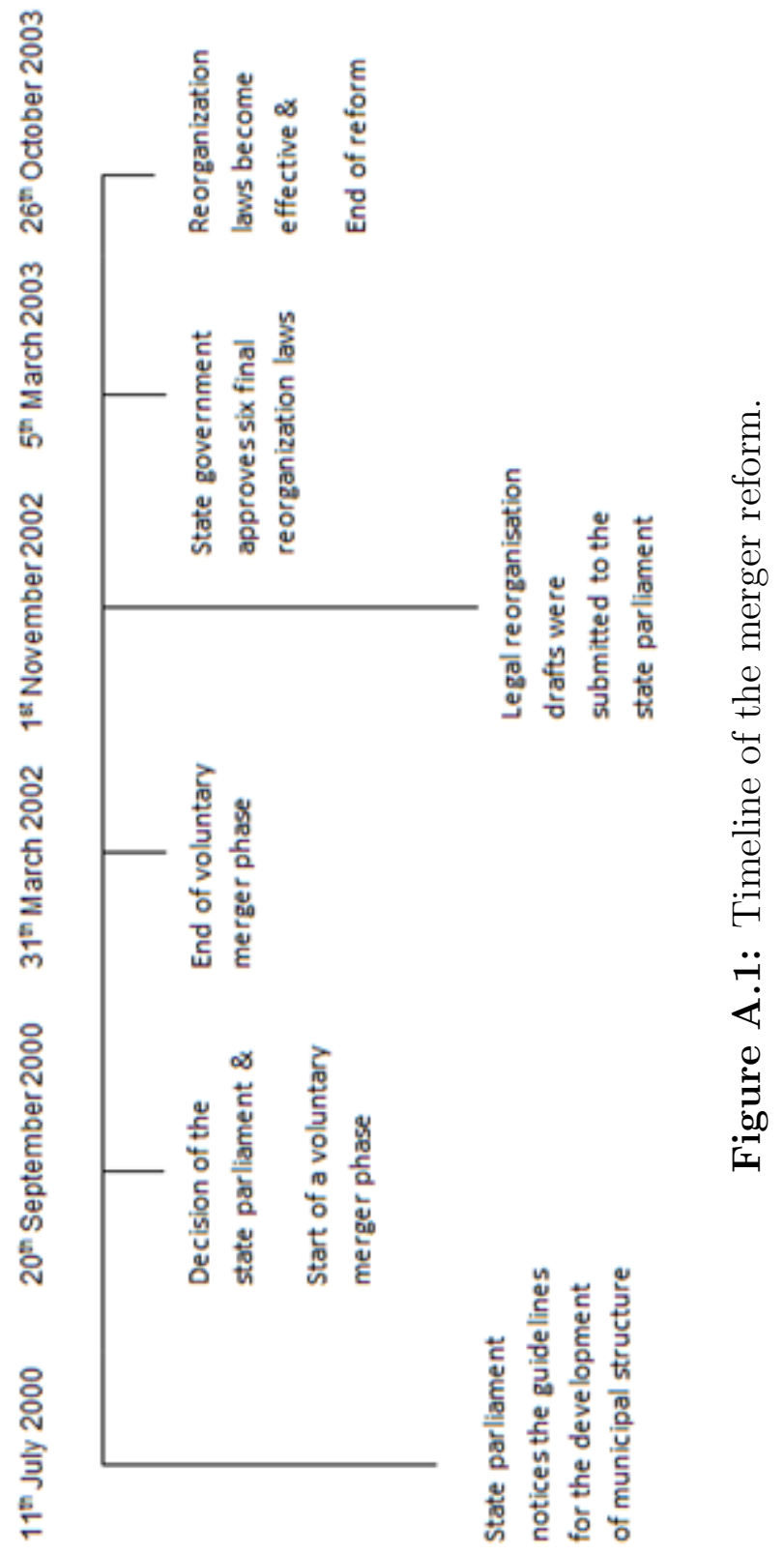



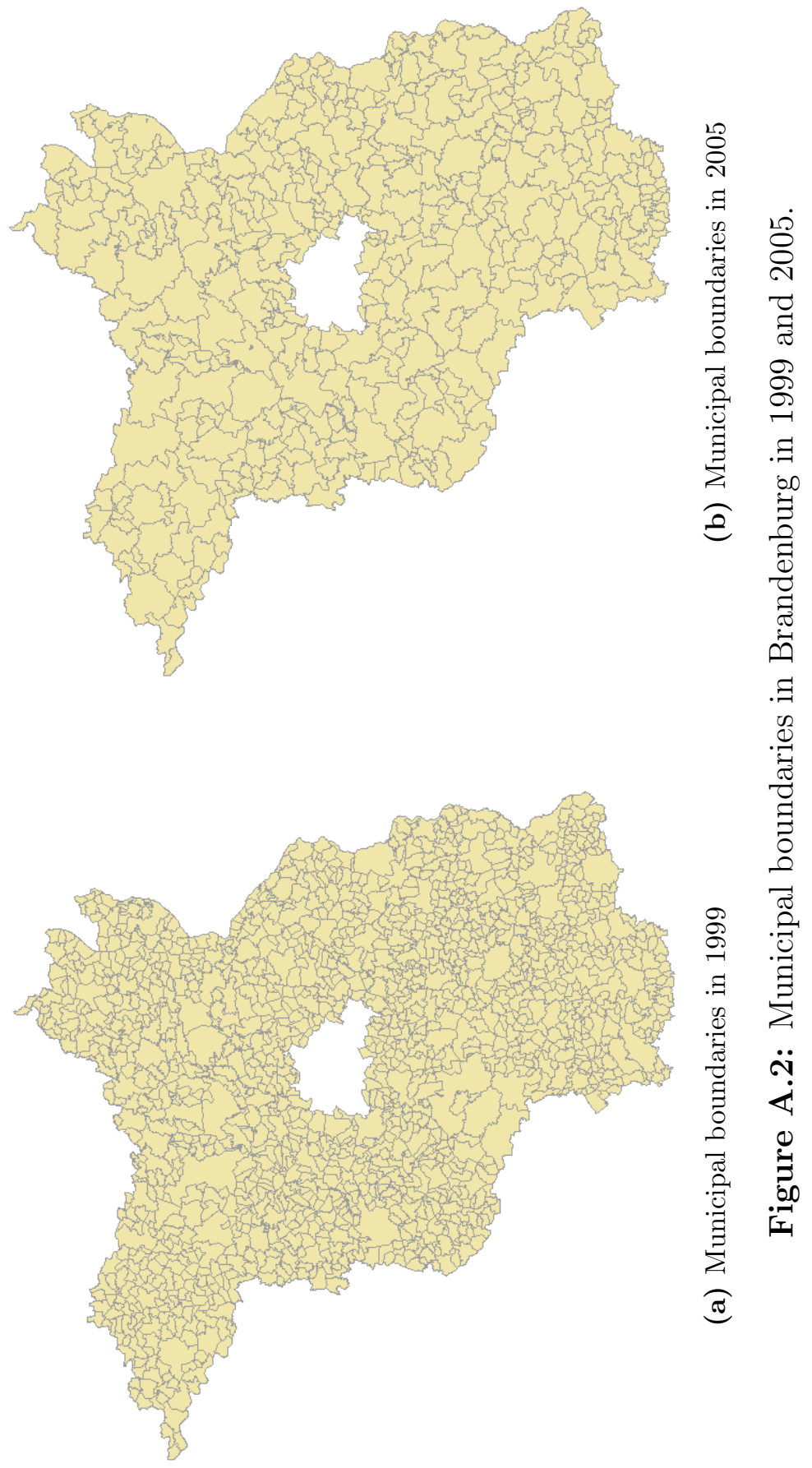


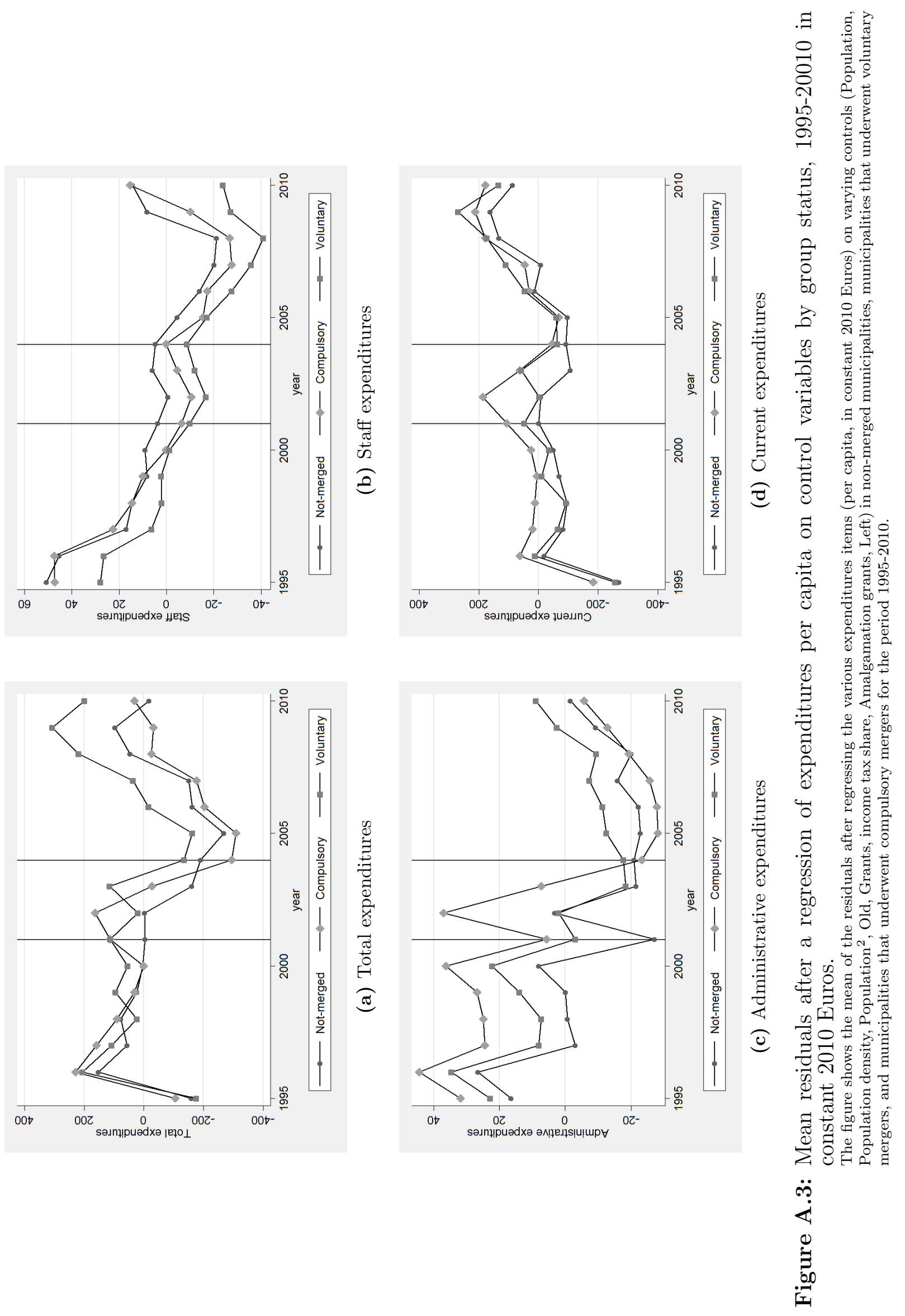

